\title{
Euphausiid predation on copepods in coastal waters of the Northeast Atlantic
}

\author{
Ulf Båmstedt*, Karin Karlson
}

University of Bergen, Department of Fisheries and Marine Biology, The High Technology Center, N-5020 Bergen, Norway

\begin{abstract}
Quantitative analyses of copepod mandibles in stomach contents of the 4 most dominant euphausiid species from the Skagerrak and the northwest coast of Norway were used to evaluate trophic interactions between copepods and krill and to develop a new method to estimate degree of carnivory in the diet. Copepods were an important food item and, based on the new method, gave a ranking in degree of carnivory mainly as Meganyctiphanes norvegica $\geq$ Thysanoessa inermis $=T$. longicaudata $\gg T$ raschii. $M$. norvegica preying on Calanus finmarchicus had similar predation rates in both laboratory studies and field samples (average 1.2 copepods ind $.^{-1} \mathrm{~h}^{-1}, 12.7 \%$ daily ration) and showed that (1) copepod mandibles were not accumulated in the predator stomach. (2) there was no ciel predation rhythm, and (3) ca $20 \%$ of copepods caught by the predator were only partly eaten, with no strong preference for the front or back part of the copepods. Carnivory was less important in the Skagerrak than in the northern area for all 3 species occurring in both areas. $T$ inermis from the Skagerrak seldom fed on copepods, whereas average carnivory in stations from the northern area ranged from 8 to $35 \%$. T. raschii usually had high stomach fullness but almost never took copepod prey. C. finmarchicus was by far the most dominant prey, making up $85 \%$ of the copepod prey mass for small M. norvegica (<50 mg dry weight) and 93 to $95 \%$ for the larger $M$. norvegica. Similar prey species dominated the other krill species. Peak size of $C$. finmarchicus prey corresponded to copepodid II for small (5 to $7.5 \mathrm{~mm}$ carapace length) $M$. norvegica, copepodid III for the larger ones, with no differences between predator sexes. Similar size distributions of $C$. finmarchicus prey were shown for $T$ inermis and $T$. longicaudata. The high daily ration on $C$. finmarchicus for $M$. norvegica, $T$. inermis and $T$. longicaudata, in combination with the commonly high abundance for both prey and predators, indicates that krill predation may contribute significantly to the mortality of $C$. finmarchicus. Furthermore, because of the pronounced importance of krill for many pelagic fish, seabirds and marine mammals in highlatitude areas, krill species may be of utmost importance in transferring copepod production to food yield for man.
\end{abstract}

KEY WORDS: Meganyctiphanes Thysanoessa - Carnivory - Ingestion - Digestion - Gut contents Predatory impact - Pelagic food chains

\section{INTRODUCTION}

Euphausiids or 'krill', although an order with only 85 species (Mauchline 1980), are distributed in all oceans and usually represent a significant fraction of the total zooplankton biomass, especially at higher latitudes (Mauchline \& Fisher 1969). At these latitudes they are often key food for the larger marine predators, from small fish and marine birds to giant whales. Many

\footnotetext{
•E-mail: ulf.baamstedt@ifm.urb.no
}

of these top predators are commercially exploited by man (cf. Mauchline \& Fisher 1969, Mauchline 1980). During the last few decades, we have also seen a development of direct fisheries based on krill stocks, especially in the Antarctic, where swarms of Euphausia superba are harvested (cf. Mauchline \& Fisher 1969, Mauchline 1980). Euphausiids can be either herbivorous or omnivorous. Economically the trophic level occupied by a species in a food chain leading to a harvest is very important. It is a well-established ecological axiom (cf. Krebs 1972) that each change in trophic level (up or down) will approximately change 
the potential production of the top predator by a factor of 5 to 10 (up or down). Initial qualitative analyses of stomach contents of different euphausiid species indicated that copepods were common prey items (MacDonald 1927, Einarsson 1945, Mauchline \& Fisher 1969, Sameoto 1980) and later, more specific enumeration of copepods in stomach contents has confirmed their dominance as prey (Stuart \& Pillar 1990, Barange et al. 1991, Gibbons et al. 1991a, b, Gibbons 1993). These rather recent studies all used a technique, in which the mandibles of the copepods were recovered, identified and enumerated from the stomach content of the predator, thereby giving a precise estimate of the number of prey eaten, but the method hitherto has been used only on euphausiids from South African waters. By measuring a specific size character of the identified copepod mandible and using an appropriate conversion to mass and size of the copepod, detailed information about species, size and developmental stage of copepod prey, as well as total copepod prey mass in stomach contents, can be obtained. The method of using copepod mandibles to quantify these parameters has been previously evaluated by Karlson \& Båmstedt (1994). By estimating total mass of stomach contents the ratio between copepod mass and total food mass in stomachs gives the degree of carnivory. With the use of an appropriate digestion rate, stomach contents can be converted to ingestion rate. Thus, the method gives a unique possibility of gathering detailed quantitative information about the feeding biology of the predator. Such information has previously not been available for the dominant species in the Northeast Atlantic. However, problems may arisefrom predator partitioning of the prey, accumulation of mandibles in the stomachs and use of inadequate methods for field sampling. We therefore present results from laboratory tests of the reliability of the method and especially evaluate the method of quantifying the degree of carnivory. Results from 3 extensive field studies in Norwegian coastal waters in spring and early summer, using the stomach analysis method, are presented for the 4 most dominant euphausiid species.

\section{MATERIAL AND METHODS}

Experimental studies. Biological material: Meganyctiphanes norvegica was collected with a $500 \mu \mathrm{m}$ mesh Isaac Kidd Midwater Trawl, equipped with a non-filtering cod end, in Raunefjorden $\left(60^{\circ} 16^{\prime} \mathrm{N}\right.$, $\left.5^{\circ} 11^{\prime} E\right)$ south of Bergen, during September-October 1992. The net was hauled obliquely for $15 \mathrm{~min}$ from $50 \mathrm{~m}$ depth to the surface. The specimens were kept in $50 \mathrm{l}$ tanks while being transported to the laboratory and then adapted for $12 \mathrm{~h}$ in a temperature controlled room with the ambient seawater temperature (10 to $12^{\circ} \mathrm{C}$ ) and 34.5 to $35 \mathrm{PSU}$. The specimens were kept in darkness all the time, except when individuals were selected for the experiments. During this time a $25 \mathrm{~W}$ red light was used. Experimental conditions were the same as during adaptation.

Copepod prey was collected in the same location the day before the experiments started. Short vertical hauls were made with a $1 \mathrm{~m}$ diameter, $300 \mu \mathrm{m}$ mesh plankton net, equipped with a non filtering cod end. In the laboratory Calanus finmarchicus copepodid stages IV, V and VI were sorted out with a wide-mouthed pipette. All experiments were conducted in the dark, and all experiments apart from one were run in $90 \mathrm{l}$ slightly conical tanks. The one exception (Expt 1) was run in a $45 \mathrm{l}$ rectangular glass aquarium. Control tanks without predators were initially run, but showed no loss of prey and were therefore omitted. The experimental tanks were filled with $20 \mu \mathrm{m}$ filtered seawater and the conical tanks used in Expts 2 to 5 were equipped with a false bottom made of plankton gauze, $1 \mathrm{~mm}$ mesh size, to prevent the krill from feeding on their own faeces. Experimental details are summarised in Table 1

Table 1 Details of the laboratory experimental design for the predator, Meganyctiphanes norvegica, and the copepod prey, Calanus finmarchicus. DW: dry weight

\begin{tabular}{|c|c|c|c|c|c|c|c|}
\hline $\begin{array}{l}\text { Expt } \\
\text { no. }\end{array}$ & $\begin{array}{l}\text { No. of } \\
\operatorname{tanks}\end{array}$ & $\begin{array}{c}\text { Tank vol. } \\
\text { (l) }\end{array}$ & $\begin{array}{l}\text { No. of } \\
\text { krill }\end{array}$ & $\begin{array}{l}\text { Krill DW } \\
\left(\mathrm{mg} \mathrm{ind}^{-1}\right)\end{array}$ & $\begin{array}{l}\text { Copepods } \\
\left(1^{-1}\right)\end{array}$ & $\begin{array}{l}\text { Incub time } \\
\text { (h) }\end{array}$ & $\begin{array}{l}\text { Experimental } \\
\text { objectives }\end{array}$ \\
\hline 1 & 5 & 45 & 1 & $8-45$ & 1.2 & 6 & Pred./dig. rate (mandible accumulation) \\
\hline 2 & 6 & 90 & 1 & $15-43$ & 1.7 & 24 & Pred./dig. rate (mandible accumulation) \\
\hline $3 a$ & 2 & 90 & $4 / 5$ & $10-36$ & 1.7 & 24 & Mandible accumulation (pred./dig. rate \\
\hline $3 b$ & 2 & 90 & $3 / 4$ & $16-49$ & 1.7 & 48 & Mandible accumulation (pred./dig. rate) \\
\hline $3 c$ & 2 & 90 & $4 / 5$ & $15-52$ & 1.7 & 72 & Mandible accumulation (pred/dig rate) \\
\hline 4 & 2 & 90 & 4 & $26-68$ & 2.0 & $4 \times 6$ & Diel feeding rhythm (pred. rate) \\
\hline 5 & 2 & 90 & 4 & $25-73$ & $2 / 10$ & 12 & Partitioning of prey (pred. rate) \\
\hline
\end{tabular}


Predation rate, daily ration and digestion time (Expts 1 to 5): In the main predation experiments (Expts 1,2 ) a given number of Calanus finmarchicus was initially added and each krill was allowed to feed for a set time. The tanks were then emptied and remaining copepods collected with a sieve and counted. Predation rate was also calculated in Expts 3 to 5 , although these experiments had other primary aims (see Table 1 and text below). The average individual predation rate was calculated as the mean number of prey removed per unit of time and converted to prey biomass by using the stage-specific dry weights given by Karlson \& Båmstedt (1994). The daily ration was defined as prey intake over $24 \mathrm{~h}$, expressed as the percentage of the predator body mass, on a dry-weight basis. Dry weights of each krill predator were calculated from carapace length and the empirical relationship given for Meganyctiphanes norvegica by Båmstedt (1976). The digestion time ( $D_{t}$, in hours) was estimated from the results on total prey ingested $\left(N_{1}\right.$, number of prey), prey left in stomach after incubation $\left(N_{\mathrm{s}}\right)$ and total incubation time ( $t$, in hours) in Expts 1 to 3 by using the formula:

$$
D_{\mathrm{t}}=N_{\mathrm{s}} \cdot t / N_{\mathrm{i}}
$$

This method assumes a constant ingestion rate, and we assumed that this was true in the experiments. It is synonymous with the method used by Peterson et al. (1990 and Irigoien et al. (1996), in which total production and gut contents of faecal pellets are used for the variables $N_{1}$ and $N_{\mathrm{s}}$ respectively. A similar method was also used by Dagg \& Walser (1987) and Pasternak (1994), in which chlorophyll in gut contents and faecal pellets were used for the variables $N_{1}$ and $N_{5}$.

Mandible retention in the stomach (Expts 1 to 3): If the prey mandibles are accumulated in the krill stomach, that will cause an overestimation of the predation rate. Assuming a constant feeding rate, this can be experimentally tested by using a gradual increase in incubation time in an experimental series. The results should then show a gradual increase in number of mandibles in the stomachs of the krill if accumulation occurs. Duplicate tanks with 3 to 5 Meganyctiphanes norvegica in each were incubated with copepods for either 24,48 or $72 \mathrm{~h}$ (Expt $3 \mathrm{a}-\mathrm{c}$ ). All experimental krill were frozen for later measurements of carapace length and analysis of stomach contents. The stomach was dissected from each krill and placed in glycerine/water (1/1) for 20 mins. Thereafter, the stomach contents were stained with methyl blue and the number of copepod mandibles counted and their width measured under a microscope (Leitz, Dialux 20) with a precision of $5 \mu \mathrm{m}$. Results from Expts 1 and $2(6$ and $24 \mathrm{~h}$ incubation, respectively) were also used in the statistical eval- uation. The significance of the correlation between number of mandibles in the stomach and incubation time was tested by a 2 -tailed $t$-test.

Feeding rhythm (Expt 4): Two tanks with 4 individual krill in each tank and a prey concentration of 2 Calanus finmarchicus $\mathrm{l}^{-1}$ were used to identify any diel feeding rhythm. The experimental krill were gently transferred by beaker after each $4 \mathrm{~h}$ period to new tanks with fresh prey. Six incubations were performed, covering the full $24 \mathrm{~h}$ day. The remaining copepods were enumerated as described above and, at the end of the experiment, the predators were frozen and treated as described above, in order to confirm their feeding state.

Partitioning of prey (Expt 5): One possible error when using stomach contents of copepod mandibles as a quantitative tool for estimating predation is the damage of prey by the predator. A preferential ingestion of the frontal part of the copepod will give a positive bias, whereas preference towards the abdominal part will cause an underestimation. Two different prey concentrations were used to determine if krill became more selective when food resources were in excess. Replicate tanks with 4 individuals were incubated for $12 \mathrm{~h}$. Tanks had a prey concentration of 2 and 10 Calanus finmarchicus $\mathrm{l}^{-1}$, respectively. After incubation, the remaining whole and partitioned prey were counted and removed items classified into 7 prey categories: whole, head, frontal half, prosome, back part, injured, and sucked out. The group 'injured' was defined as individuals that were missing minor parts of the body (e.g. legs, antennae) or showed a minor deformation.

Field investigations. Biological material: Krill were collected during 3 cruises in 2 different areas (Fig. 1). Cruises 1 (RV 'Eldjarn') and 2 (RV 'Håkon Mosby') were carried out off the northwest coast of Norway $\left(64^{\circ} 50^{\prime} \mathrm{N}, 5^{\circ} 70^{\prime} \mathrm{E}\right.$ to $\left.69^{\circ} 60^{\prime} \mathrm{N}, 17^{\circ} 80^{\prime} \mathrm{E}\right)$ from 16 to 22 May and 19 June to 1 July 1990, respectively. A Harstad midwater trawl (Nederaas \& Smestad 1987) with a $30 \mathrm{~m}$ long trawl bag with $8 \mathrm{~mm}$ mesh size was hauled horizontally for $30 \mathrm{~min}$ at $50 \mathrm{~m}$ and 3 knots speed. Sixty stations were sampled during cruise 1 and 55 during cruise 2. Zooplankton samples were taken during cruise 2 with a WP2 net, $180 \mu \mathrm{m}$ mesh, by 2 combined hauls, 300 to 50 and 50 to $0 \mathrm{~m}$. The samples were fractionated ( 0.2 to 1.0 and 1 to $2 \mathrm{~mm})$ and frozen for later dry-weight determination $\left(60^{\circ} \mathrm{C}\right.$ to constant weight). Cruise 3 (RV 'G.O. Sars') was carried out in the Skagerrak (Fig. 1) between the south coast of Norway and the west coast of Sweden $\left(57^{\circ} 30^{\prime} \mathrm{N}, 7^{\circ} 20^{\prime} \mathrm{E}\right.$ to $58^{\circ} 10^{\prime} \mathrm{N}, 11^{\circ} 10^{\prime}$ E) from 15 to 29 April 1991. A MIK (Modified Isaac-Kidd) Midwater Trawl with $1.2 \mathrm{~mm}$ mesh size, reduced to $0.5 \mathrm{~mm}$ in the end part, was hauled horizontally for 10 to $45 \mathrm{~min}$ between 30 and $170 \mathrm{~m}$ depth at a speed of 3 knots. Forty-one stations 


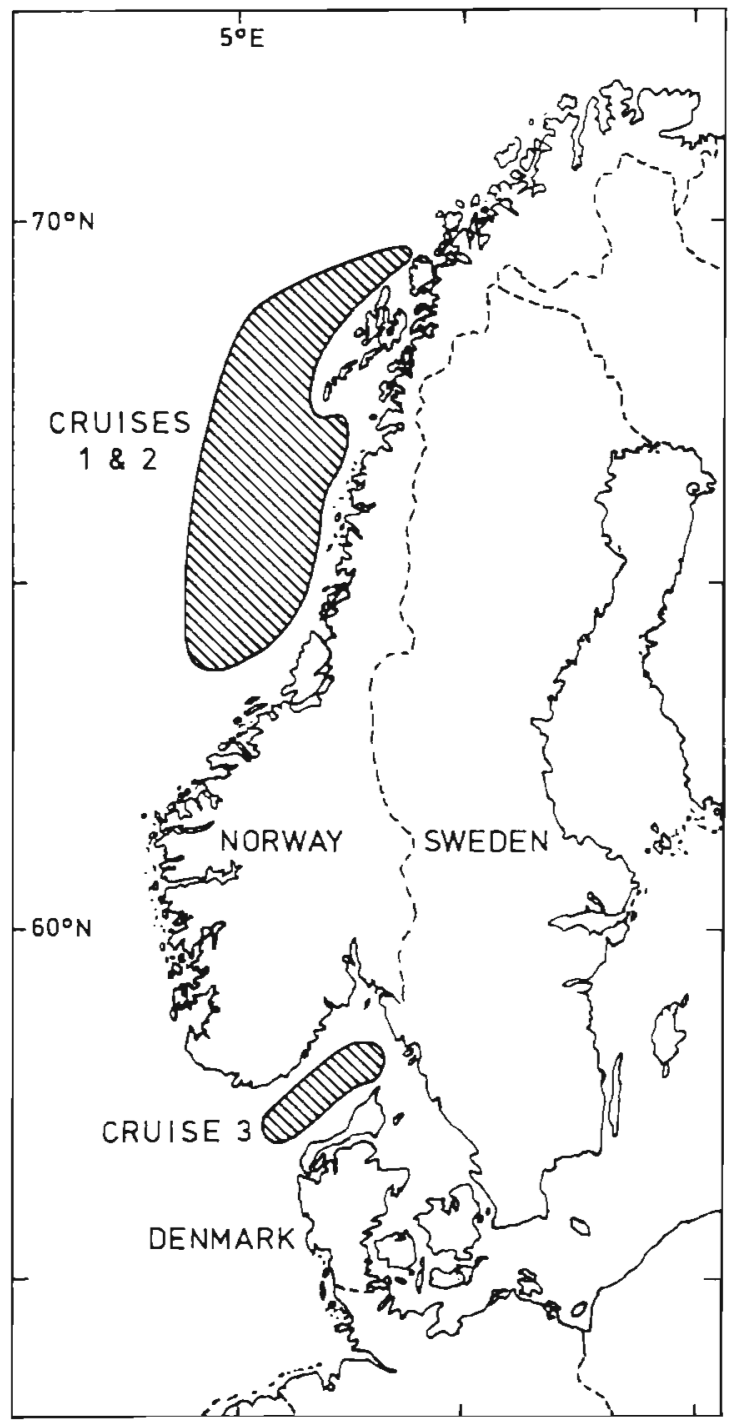

Fig. 1. Map of the field sampling areas. Cruises 1 and 2 northern sampling area with the RV 'Eldjarn' and the RV 'Hảkon Mosby' in 1990. Cruise 3: southern (Skagerrak) sampling area with the RV 'G.O. Sars' cruise in 1991

were sampled. Vertically divided zooplankton samples were taken with a WP2 net, $180 \mu \mathrm{m}$ mesh, in the depth intervals $110-35,35-15$ and $15-0 \mathrm{~m}$. These were preserved in $4 \%$ buffered formaldehyde and copepods were later identified and counted in the laboratory. Results for a single day were used in the present paper. Details of position, sampling time and sample size of analysed krill individuals are given in Table 2 . During both cruises 1 and 2, 11 stations (18 and $20 \%$, respectively) gave krill catches. During cruise 3, 22 stations $(54 \%)$ gave krill catches. All krill were immediately frozen and stored for later stomach analyses in the laboratory.
Laboratory analyses of krill stomachs: In the laboratory, samples were thawed, species identified and the carapace length measured under a dissection microscope before the stomach was dissected from the krill. Stomach fullness was classified from visual inspection in the microscope into 5 categories: empty, 25, 50, 75 and $100 \%$ full, and thereafter stomach analyses were performed as described above. The mandibles from krill sampled during cruises 1 and 2 were identified as either Calanus finmarchicus, Metridia sp. or unidentified. The mandibles from cruise 3 were identified more precisely, according to the key descriptions by Karlson \& Bamstedt (1994). The total dry weight of copepods in the stomach was calculated from relationships between mandible width and dry weight according to Karlson \& Båmstedt (1994) and dividing the sum by 2 (2 mandibles per copepod). For C. finmarchicus, an intraspecific relationship was used; for the others, except Temora longicornis, a general relationship was used. T. longicornis has significantly wider mandibles for a given prosome length (Karlson \& Båmstedt 1994), so the species-specific relationship was used. The dry weights for all krill species were calculated from the carapace length, using the seasonally specific relationships for Meganyctiphanes norvegica given by Bảmstedt (1976).

Predation rate, daily ration and degree of carnivory, based on field samples: The predation rate on copepods was given by summing up the individual dry weights of copepods in the stomachs and multiplying by the stomach turnover rate $\left(1 / D_{t}\right)$ The daily ration was calculated as the summed ingestion of copepod dry weight over $24 \mathrm{~h}$, expressed as percentage of the predator dry weight. Calculations of the degree of carnivory were based on the following logic: among a group of omnivorous individuals, some will probably only have copepods in their stomach. If stomach content, expressed as \% of krill weight $(Y)$, is plotted against stomach fullness ( $X$, scale from 0 to 1$)$, a straight line from the origin through the highest $Y / X$ ratio will therefore give an estimate of the relationship between relative weight of the stomach content (as \% of the predator weight) and the relative stomach fullness, and is here called $C_{\max }$. The degree of carnivory can thus be estimated as the ratio between the copepod biomass actually found $\left(C_{\text {found }}\right)$ and $C_{\text {max }}$, i.e

$$
\% \text { carnivory }=\left(C_{\text {found }}\right) /\left(C_{\text {max }}\right) \cdot 100 \%
$$

where $C_{\max }$ is defined by the line from the origin to the highest $Y / X$ point. The validity of this method is discussed later. The term carnivory is here given a restricted meaning by considering copepods as the only carnivorous food, and this implies that true carnivory may be higher 


\section{RESULTS}

\section{Experiments}

Predation rate and daily ration of Meganyctiphanes norvegica (Fig. 2)

The predation rate in the 5 different experiments (Expts 1, 2, 3a-c) varied between 0 and 3.2 copepods $\mathrm{h}^{-1}$, with the highest rates recorded for the largest

Table 2. Station data and number of individual krill (females + males) analysed from the different stations. M.n.: Meganyctiphanes norvegica; T.i.: Thysanoessa inermis; T.l: T. longicaudata; T.I.: T. raschii

\begin{tabular}{|c|c|c|c|c|c|c|c|c|}
\hline \multirow{2}{*}{$\begin{array}{l}\text { Cruise/ } \\
\text { date }\end{array}$} & \multirow{2}{*}{$\begin{array}{c}\text { Position } \\
\text { (Lat. } N \text {, Long. E) }\end{array}$} & \multirow[t]{2}{*}{ Stn } & \multirow{2}{*}{$\begin{array}{l}\text { Depth } \\
\text { (m) }\end{array}$} & \multirow{2}{*}{$\begin{array}{l}\text { Time } \\
\text { (h) }\end{array}$} & \multicolumn{4}{|c|}{ Species } \\
\hline & & & & & M.n. & $T i$ & $T I$. & T.r. \\
\hline \multicolumn{9}{|c|}{ Eldjarn 1990 (cruise 1) } \\
\hline May 16 & $66^{\circ} 58^{\prime}, 07^{\circ} 10^{\prime}$ & 229 & $0-60$ & $14.00-14.30$ & & $6+3$ & $8+1$ & \\
\hline May 16 & $67^{\circ} 07^{\prime}, 06^{\circ} 20^{\prime}$ & 230 & $0-60$ & $16.30-17.00$ & & $7+4$ & $9+0$ & \\
\hline May 18 & $67^{\circ} 00^{\prime}, 11^{\circ} 50^{\prime}$ & 242 & $0-60$ & $00.30-01.00$ & $14+6$ & & & \\
\hline May 18 & $67^{\circ} 30^{\prime}, 09^{\circ} 40^{\prime}$ & 245 & $0-60$ & $09.15-09.45$ & & $0+9$ & & \\
\hline May 19 & $67^{\circ} 20^{\prime}, 12^{\circ} 35^{\prime}$ & 251 & $0-60$ & $02.45-03.15$ & $5+1$ & $11+0$ & & \\
\hline May 19 & $67^{\circ} 58^{\prime}, 12^{\circ} 40^{\prime}$ & 256 & $0-60$ & $16.00-16.30$ & & $10+1$ & & \\
\hline May 19 & $68^{\circ} 10^{\prime}, 11^{\circ} 50^{\prime}$ & 257 & $0-60$ & $18.30-19.00$ & & $8+1$ & & \\
\hline May 20 & $68^{\circ} 56^{\prime}, 10^{\circ} 36^{\prime}$ & 261 & $0-60$ & $05.45-06.15$ & & & $8+1$ & \\
\hline May 20 & $68^{\circ} 46^{\prime}, 11^{\circ} 39^{\prime}$ & 262 & $0-60$ & $08.30-09.00$ & & & & $8+1$ \\
\hline May 20 & $68^{\circ} 36^{\prime}, 12^{\circ} 30^{\prime}$ & 263 & $0-60$ & $11.00-11.30$ & & $8+1$ & & \\
\hline May 21 & $69^{\circ} 15^{\prime}, 15^{\circ} 10^{\prime}$ & 274 & $0-60$ & $15.30-16.00$ & $13+5$ & & & \\
\hline May 22 & $69^{\circ} 56^{\prime}, 17^{\circ} 00^{\prime}$ & 280 & $0-60$ & $06.10-06.40$ & & $2+4$ & & \\
\hline \multicolumn{9}{|c|}{ H. Mosby 1990 (cruise 2) } \\
\hline June 19 & $69^{\circ} 35^{\circ}, 17^{\circ} 30^{\prime}$ & 17 & $0-210$ & $22.00-22.30$ & $2+7$ & $4+1$ & & \\
\hline June 20 & $69^{\circ} 20^{\prime}, 12^{\circ} 15^{\prime}$ & 25 & $0-40$ & $21.00-21.30$ & & & $15+0$ & \\
\hline June 21 & $69^{\circ} 20^{\prime}, 10^{\circ} 52^{\prime}$ & 26 & $0-40$ & $01.30-02.00$ & & $9+0$ & & \\
\hline June 21 & $68^{\circ} 04^{\prime}, 11^{\circ} 00^{\prime}$ & 29 & $0-40$ & $19.00-19.30$ & & $5+4$ & & \\
\hline June 24 & $67^{\circ} 05^{\prime}, 08^{\circ} 55^{\prime}$ & 39 & $0-60$ & $23.30-00.00$ & $2+7$ & & $8+0$ & \\
\hline June 24 & $67^{\circ} 05^{\prime}, 07^{\circ} 30^{\prime}$ & 41 & $0-60$ & $09: 00-09.30$ & & & $9+0$ & \\
\hline June 24 & $67^{\circ} 05^{\prime}, 06^{\circ} 50^{\prime}$ & 42 & $0-60$ & $13.30-14.00$ & & & $4+5$ & \\
\hline June 24 & $66^{\circ} 58^{\prime}, 07^{\circ} 37^{\prime}$ & 43 & $0-60$ & $21.00-21.30$ & & & $9+0$ & \\
\hline June 24 & $66^{\circ} 50^{\prime}, 08^{\circ} 00^{\prime}$ & 44 & $0-60$ & $23.30-24.00$ & & $5+1$ & $3+1$ & \\
\hline June 25 & $66^{\circ} 40^{\prime}, 08^{\circ} 50^{\prime}$ & 45 & $0-60$ & $07.30-08.00$ & & $5+4$ & & \\
\hline June 25 & $64^{\circ} 30^{\prime}, 09^{\circ} 12^{\prime}$ & 51 & $0-60$ & $01.00-01.30$ & $4+5$ & & & \\
\hline \multicolumn{9}{|c|}{ G.O. Sars 1991 (cruise 3) } \\
\hline April 19 & $57^{\circ} 37^{\prime}, 10^{\circ} 41^{\prime}$ & 6 & 103 & $00.03-00.31$ & $7+2$ & & & $6+2$ \\
\hline April 19 & $57^{\circ} 37^{\prime}, 10^{\circ} 41^{\prime}$ & 7 & 30 & $00.35-00.42$ & $9+0$ & & & $4+6$ \\
\hline Aprl 19 & $58^{\circ} 03^{\prime}, 10^{\circ} 33^{\prime}$ & 8 & 75 & $01.50-02.10$ & $8+1$ & & & $5+3$ \\
\hline Aprl 19 & $58^{\circ} 05^{\prime}, 10^{\circ} 42^{\prime}$ & 9 & 56 & $02.50-03.12$ & $1+8$ & & & \\
\hline April 19 & $58^{\circ} 08^{\prime}, 10^{\circ} 22^{\prime}$ & 11 & 110 & $20.30-20.56$ & $3+6$ & & & $8+1$ \\
\hline April 19 & $58^{\circ} 04^{\prime}, 10^{\circ} 20^{\prime}$ & 12 & 100 & $21.32-21.59$ & $5+5$ & $2+0$ & & $6+0$ \\
\hline Aprol 20 & $58^{\circ} 04^{\prime}, 10^{\circ} 20^{\prime}$ & 13 & 100 & $22.29-22.52$ & $3+6$ & & & $8+1$ \\
\hline April 20 & $57^{\circ} 59^{\prime}, 10^{\circ} 17^{\prime}$ & 14 & 70 & $23.24-23.40$ & $1+2$ & $6+1$ & & $4+2$ \\
\hline April 20 & $57^{\circ} 55^{\prime}, 10^{\circ} 27^{\prime}$ & 15 & & & & $2+1$ & & $6+2$ \\
\hline April 20 & $57^{\circ} 57^{\prime}, 10^{\circ} 36^{\prime}$ & 16 & 100 & $01.23-01.49$ & $3+6$ & & & $5+4$ \\
\hline April 20 & $57^{\circ} 52^{\prime}, 10^{\circ} 35^{\prime}$ & 17 & & & & $4+0$ & & 6 \\
\hline April 20 & $57^{\circ} 59^{\prime}, 10^{\circ} 42^{\prime}$ & 18 & 150 & $21.05-21.45$ & $4+5$ & & & $4+1$ \\
\hline April 21 & $58^{\circ} 01^{\prime}, 10^{\circ} 49^{\prime}$ & 19 & 101 & $22.28-22.37$ & $4+5$ & & & $7+2$ \\
\hline April 21 & $58^{\circ} 02^{\prime}, 10^{\circ} 57^{\prime}$ & 20 & 170 & $22.54-23.04$ & $3+6$ & & & $7+2$ \\
\hline April 21 & $58^{\circ} 02^{\prime}, 10^{\circ} 57^{\prime}$ & 21 & 145 & $00.05-00.28$ & $4+5$ & $3+0$ & $9+0$ & $3+3$ \\
\hline April 21 & $58^{\circ} 03^{\prime}, 11^{\circ} 04^{\prime}$ & 22 & 100 & $01.15-01.28$ & $7+2$ & & & $7+2$ \\
\hline April 24 & $57^{\circ} 36^{\prime}, 07^{\circ} 21^{\prime}$ & 30 & 170 & $21.47-22.31$ & $3+6$ & & & $7+2$ \\
\hline April 24 & $57^{\circ} 28^{\prime}, 07^{\circ} 27^{\prime}$ & Trawl & 100 & $23.43-00.13$ & $5+4$ & & & $9+0$ \\
\hline April 25 & $57^{\circ} 22^{\prime}, 07^{\circ} 31^{\prime}$ & 31 & & & & & & $5+4$ \\
\hline April 26 & $58^{\circ} 06^{\prime}, 08^{\circ} 22^{\prime}$ & 37 & & & & & & $7+2$ \\
\hline April 26 & $58^{\circ} 02^{\prime}, 08^{\circ} 52^{\prime}$ & 39 & 53 & $01.47-02.04$ & $7+2$ & & & $6+3$ \\
\hline April 26 & $58^{\circ} 02^{\prime}, 08^{\circ} 51^{\prime}$ & 40 & 170 & $02.15-02.52$ & $4+5$ & & & $9+0$ \\
\hline
\end{tabular}

krill, although the effect of predator size was weak in our data. The average predation rate from all experiments was 1.2 copepods ind. ${ }^{-1} \mathrm{~h}^{-1}(\mathrm{SD}=0.86, \mathrm{n}=28)$. The corresponding daily ration ranged from 0 to $33 \%$, without any significant effect of predator size, with an average value of $12.7 \%(\mathrm{SD}=8.06)$.

The digestion time was calculated as $3.35 \pm 1.74 \mathrm{~h}$ (Table 3). Two of the 16 individual results diverged ( $D_{t}=14.5$ and $9.0 \mathrm{~h}$ ) and if these were excluded the average digestion time was reduced to $2.15 \mathrm{~h}$. Earlier results on euphausiid digestion of copepods indicate even much shorter times, e.g. 1.3 h for Euphausia lucens (Stuart \& Pillar 1990) and 0.25 to $0.5 \mathrm{~h}$ for Meganyctiphanes norvegica (Heyraud 1979). In our calculations of predation rates from stomach contents, we therefore used a somewhat subjectively reduced value of $3.0 \mathrm{~h}$ for the digestion time, which still must be considered as a conservative estimate.

\section{Mandible retention in the stomach}

For the 4 incubation times tested, predation rates varied between 0.8 and 2.0 copepods ind.$^{-1} \mathrm{~h}^{-1}$ Therefore, the number of mandibles recovered from the stomach analyses should be comparable. Stomach content for the in total 70 individuals in the experiments ranged from zero to 23 mandibles, with small differences among the 4 incubation times: $6.3 \pm 2.7$, $5.8 \pm 2.0,5.7 \pm 3.9$ and $4.8 \pm 2.5$ mandibles (average $\pm 95 \%$ confidence interval) for $6,24,48$ and $72 \mathrm{~h}$ incubation, respectively. There was no significant correlation between number of mandibles in the stomachs and incubation time ( $t$-test, $p>0.05)$, indicating that the number of mandibles present in stomach contents reflects the ingestion rate.

\section{Feeding rhythm}

The average predation rate of the 2 experimental groups was 1.99 and 2.05 copepods ind ${ }^{-1} \mathrm{~h}^{-1}$, and both groups showed considerable variability between the $4 \mathrm{~h}$ incubations. The average predation rate for the 

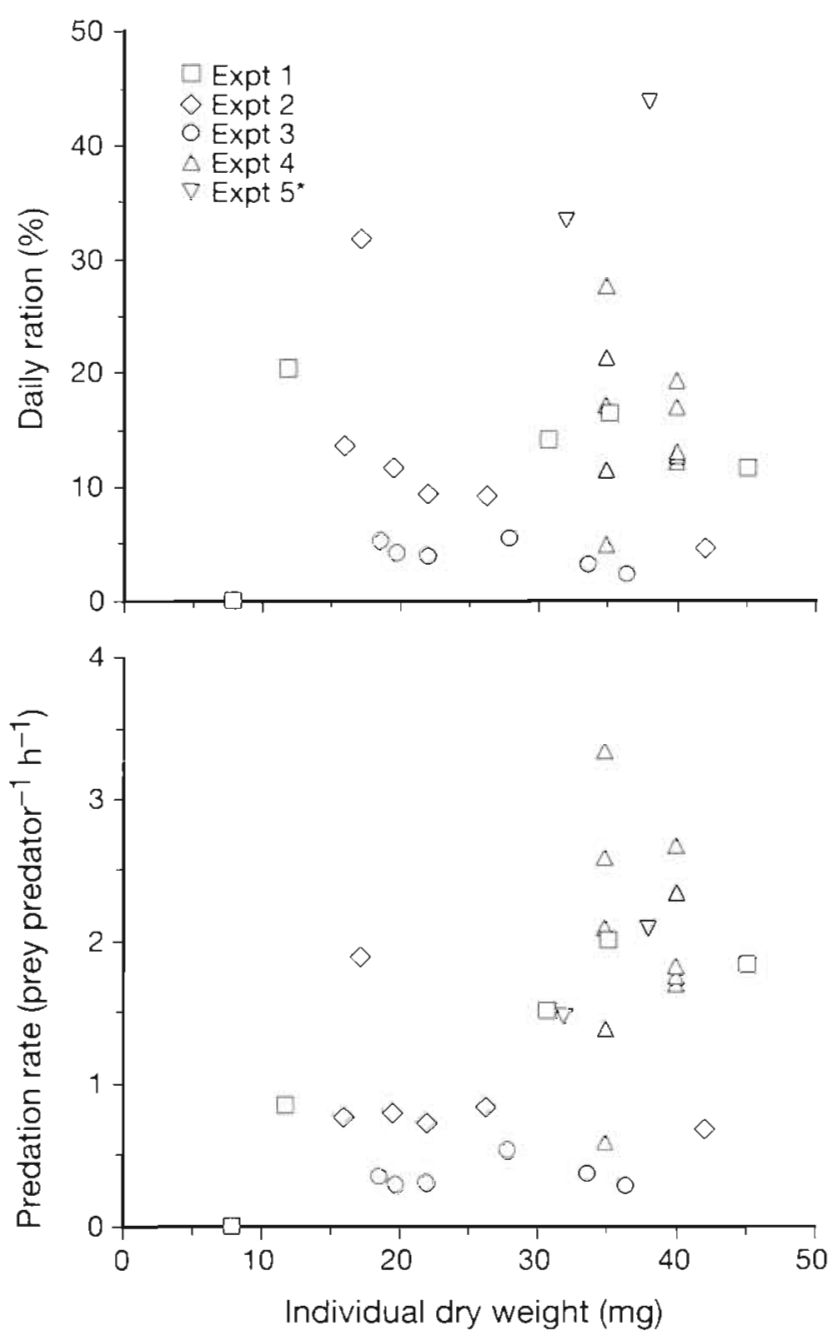

Fig. 2. Meganyctiphanes norvegica. Daily ration and predation rate from laboratory experiments. - In Expt 5, predation rate has been calculated on the basis of all prey processed, partly eaten prey thus giving an overestimation of the predation rate and daily ration (cf. Fig. 3)
Table 3. Meganyctiphanes norvegica. Estimation of digestion time with Calanus finmarchicus as food, using Eq. (1) and assuming a constant predation rate. Four krill that did not feed (no copepod mandibles in the stomach) have been excluded from the calculations

\begin{tabular}{|lccccc}
\hline $\begin{array}{l}\text { Expt } \\
\text { no. }\end{array}$ & $\begin{array}{c}\text { No. of } \\
\text { tanks }\end{array}$ & $\begin{array}{c}\text { No. of krill } \\
\text { per tank }\end{array}$ & $\begin{array}{c}\text { No. of cop. } \\
\text { eaten }\end{array}$ & $\begin{array}{c}\text { No. of cop. } \\
\text { in stomach }\end{array}$ & $\begin{array}{c}\text { Digestion } \\
\text { time (h) }\end{array}$ \\
\hline 1 & 4 & 1 & $5-12$ & $1-6$ & $1.2-3.0$ \\
2 & 6 & 1 & $16-45$ & $1.5-11.5$ & $2.0-14.5$ \\
$3 \mathrm{a}-\mathrm{c}$ & 6 & $3-5$ & $27-105$ & $3-19$ & $1.0-2.7$
\end{tabular}

Average digestion time $\pm 95 \%$ confidence intervals ( $n=16)$ : $3.35 \pm 1.74$

$4 \mathrm{~h}$ incubations ranged from 1.5 prey $\mathrm{h}^{-1}$ at noon to 2.6 prey $\mathrm{h}^{-1}$ in early morning. Although the material was too small for a meaningful statistical evaluation, these results indicate that there was at least no strong diel internal feeding rhythm that could bias the experimental results.

\section{Prey partitioning (Fig. 3)}

In the higher prey concentration $\left(10 \mathrm{l}^{-1}\right)$ copepods were entirely consumed in $78 \%$ of the predation occasions, whereas $80 \%$ were entirely consumed in the lower concentration $\left(2 \mathrm{r}^{-1}\right)$. Among the partly eaten copepods, the frontal part of the prey (e.g. including the mandibles) was eaten in $61 \%$ of the cases in the high prey concentration and in $36 \%$ of the cases in the low one. The back part (e.g. excluding the mandibles) was eaten in $18 \%$ of the cases in the high prey concentration and in $29 \%$ of the cases in the low one. The remaining prey were either injured or sucked out, leaving almost the whole carcass intact. This type of prey made
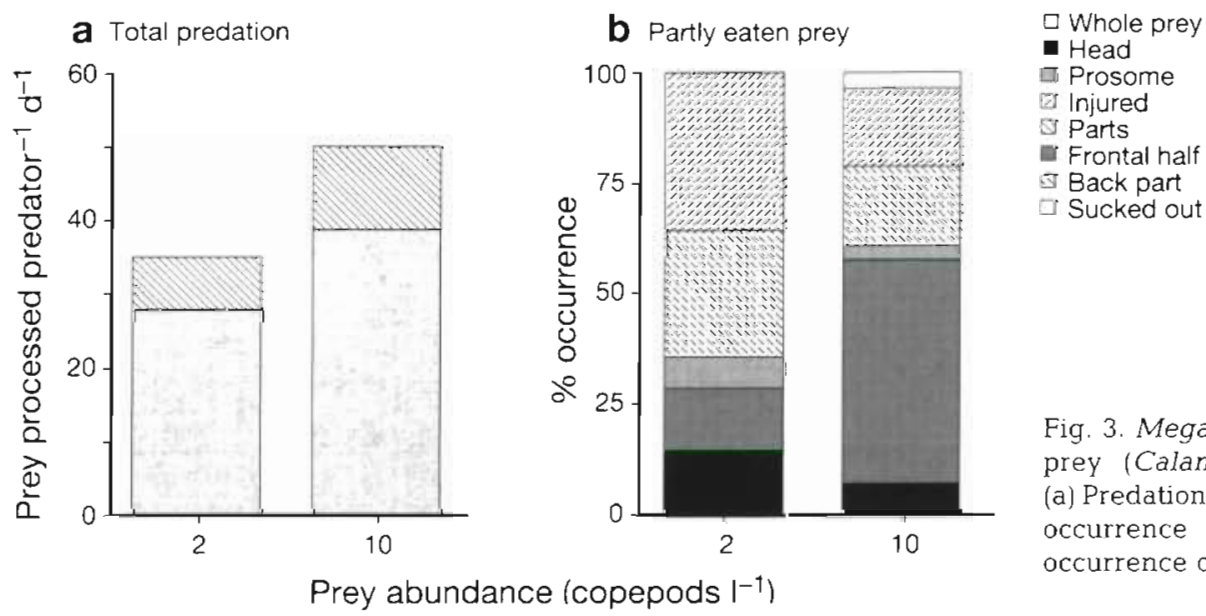

Fig. 3. Meganyctiphanes norvegica. Treatment of prey (Calanus finmarchicus) during ingestion. (a) Predation rate at 2 prey concentrations, showing accurrence of partly eaten prey. (b) Relative. occurrence of predation treatment of partly eaten prey 
Table 4. Comparison of the daily ration (DR) of specimens collected in the daytime (03:00 to 21:00 h) and night-time (21:00 to 03:00 h) during cruises 1 and 2. n: number of specimens analysed; $\mathrm{Cl}$ : $95 \%$ confidence interval; p: probability of no difference between day and night samples

\begin{tabular}{|lrcccccc|}
\hline \multirow{2}{*}{ Species } & \multicolumn{3}{c}{ Day samples } & \multicolumn{3}{c|}{ Night samples } \\
& $\mathrm{n}$ & $\mathrm{DW}(\mathrm{mg}) \pm \mathrm{Cl}$ & $\mathrm{DR} \% \pm \mathrm{Cl}$ & $\mathrm{n}$ & $\mathrm{DW}(\mathrm{mg}) \pm \mathrm{Cl}$ & $\mathrm{DR} \% \pm \mathrm{Cl}$ \\
\hline Meganyctiphanes norvegica & 9 & $59.42 \pm 18.85$ & $1.11 \pm 0.68$ & 40 & $45.96 \pm 5.01$ & $8.53 \pm 2.36$ & 0.0063 \\
Thysanoessa inermis & 76 & $27.96 \pm 2.24$ & $5.08 \pm 1.57$ & 30 & $32.19 \pm 3.94$ & $4.46 \pm 1.61$ & 0.653 \\
Thysanoessa longicaudata & 39 & $5.81 \pm 0.77$ & $3.83 \pm 2.29$ & 35 & $8.00 \pm 0.52$ & $4.21 \pm 1.75$ & 0.797 \\
\hline
\end{tabular}

up $21 \%$ of the partly eaten copepods in the high prey concentration and $36 \%$ in the low prey concentration. Sucking out the prey would result in a high negative bias, while ingestion of the head a high positive bias, but neither of these 2 behaviours was common. A strong dominance of whole prey in the diet and selection of both frontal and back parts of the prey when only partly eaten thus indicate that stomach contents of copepod mandibles give a true estimate of prey mass.

\section{Field populations}

\section{An overview}

Four krill species occurred in the samples, Meganyctiphanes norvegica, Thysanoessa inermis, T. longicaudata and $T$. raschii. $M$. norvegica was the most widespread species, common in both sampling areas. $T$. inermis also occurred in both areas, whereas $T$.
Iongicaudata and $T$. raschii were almost exclusively restricted to the northern area and the Skagerrak area (see Table 2).

All sampling in the Skagerrak was carried out at night between 20:30 and 02:50 h (cf. Table 2), so no evaluation of diel feeding rhythm was done. In the northern area, sampling times during the 2 cruises were spread over the day (cf. Table 2), and the results on the daily ration were therefore tested by a 2 -tailed $t$-test, where the night was defined as between 21:00 and 03:00 h, daytime between 03:00 and 21:00 h. For this purpose all sampled individuals were defined as either day or night krill and no attention was made to other aspects of the sampling. The results (Table 4) indicated that Meganyctiphanes norvegica had a significantly higher daily ration during the night ( $\mathrm{p}=$ 0.0063 ) whereas Thysanoessa inermis and $T$. longicaudata had not $(\mathrm{p}>0.05)$.

In order to evaluate any dependence of krill occurrence on prey biomass, zooplankton biomass in the
Fig. 4. Meganyctiphanes norvegica. Average values of basic data related to the nutritional ecology of the species, shown for each field sampling station separately. Vertical thin lines denote $95 \%$ confidence limits. E: cruise 1 with RV 'Eldjarn'; H: cruise 2 with RV 'Håkon Mosby', G: cruise 3 with RV 'G.O. Sars' Logistic data of the sampling given in Table 2
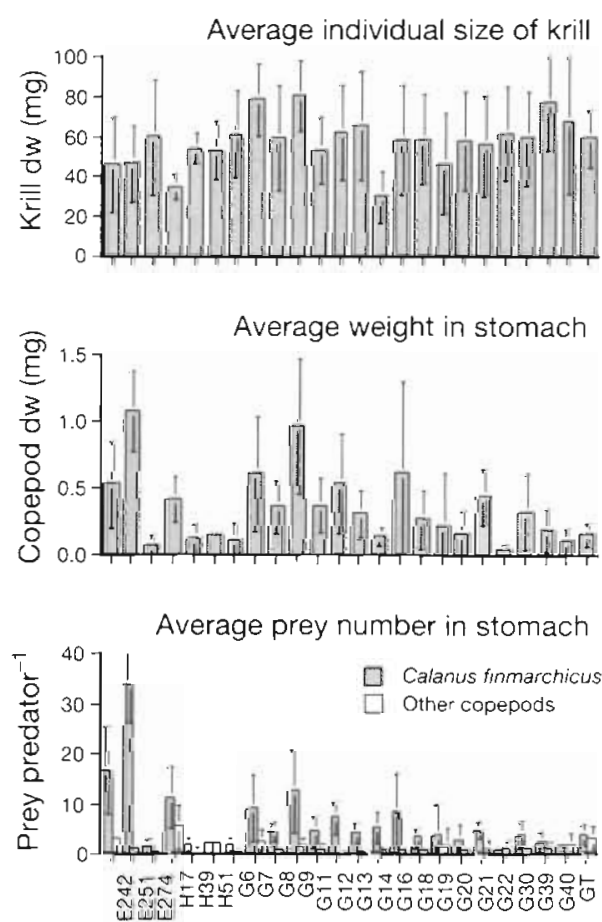

Dominance of C. finmarchicus
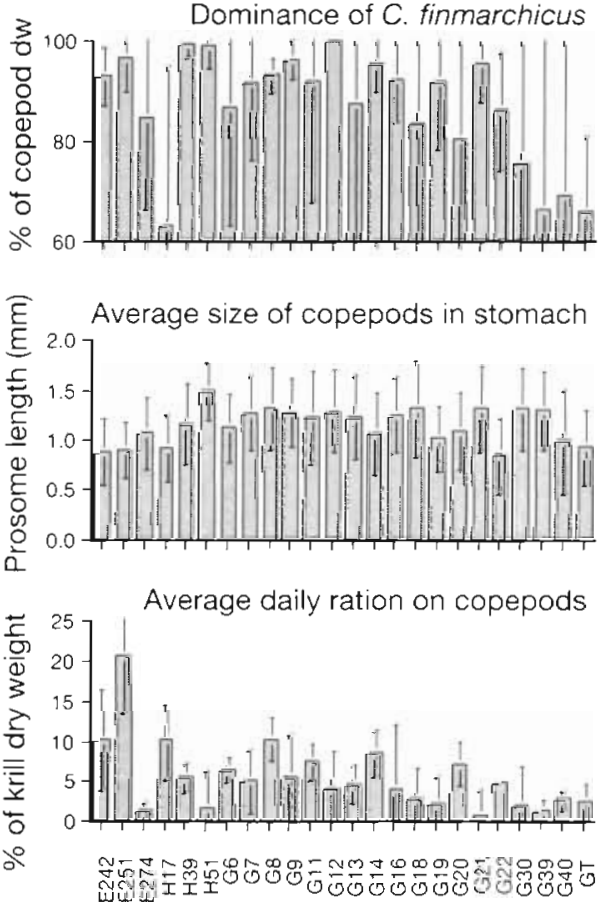

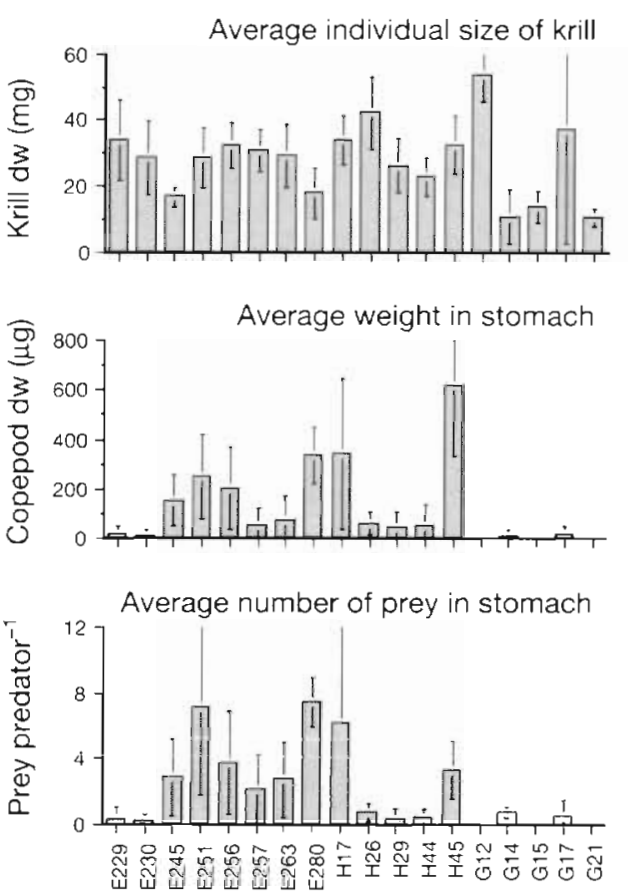
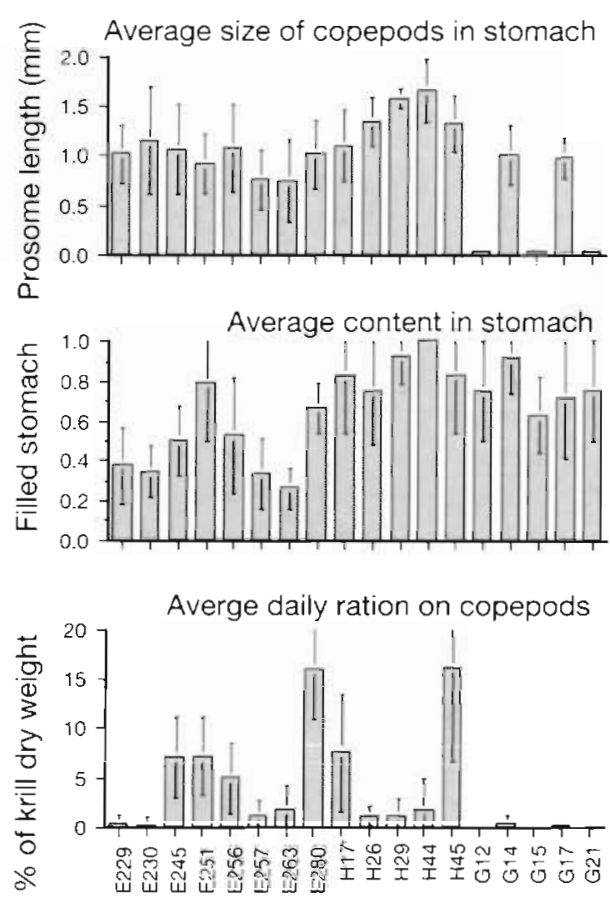

Fig. 5. Thysanoessa inermis. Average values of basic data related to the nutritional ecology of the species. Prey was almost exchusively Calanus finmarchicus. See Fig. 4 for abbreviations stations taken during the RV 'Håkon Mosby' cruise (cruise 2) were compared with the occurrence of krill. At least 1 species of krill was present in 8 of the 27 stations, representing both high and low zooplankton biomass. Only 2 of these stations, representing among the highest and a lowest zooplankton biomass, had more than 1 krill species. Because of this lack of correlation between krill occurrence and zooplankton biomass we conclude that the availability of prey was not a significant factor defining krill occurrence.

\section{Krill species}

Meganyctiphanes norvegica (Fig. 4). This species showed a range in average dry weight (over all stations) from 35 to $80 \mathrm{mg}$. Average stomach contents of copepods varied between 0.1 and $1.1 \mathrm{mg}$ dry weight or between 2 and 34 Calanus finmarchicus ( 1 to 3 other copepod species), and $C$. finmarchicus amounted to between 63 and $100 \%$ of the total copepods eaten. The average prosome length of eaten copepods varied between stations from 0.85 to $1.5 \mathrm{~mm}$. Finally, the average daily ration of $M$. norvegica, based on copepod intake, varied between 1 and $20 \%$.

Thysanoessa inermis (Fig. 5). The average dry weight of this species ranged from 10 to $54 \mathrm{mg}$ Stomach content ranged from zero to $0.6 \mathrm{mg}$ dry weight or 0 to 7 copepods (almost exclusively Calanus finmarchicus). The average size of copepods in the stomach content varied from 0.1 to $1.6 \mathrm{~mm}$ prosome length and the daily ration on a copepod diet from zero to $16 \%$.

Thysanoessa longicaudata (Fig. 6). This was the smallest of the 4 krill species, ranging in average size from 4 to $9 \mathrm{mg}$ dry weight. The average number of prey in the stomach varied from 0.2 to 1.1 copepods and the size of these prey ranged from 1.0 to $1.9 \mathrm{~mm}$ prosome length. The average stomach fullness (all food included) ranged from 0.2 to 0.7 and the daily ration on copepods varied between 2 and $7 \%$

Thysanoessa raschii (Fig. 7). Individual dry weight varied between 9 and $28 \mathrm{mg}$. Copepod mandibles were only found a few times in the stomach contents, but average stomach fullness was usually high, ranging from 0.3 to 0.9 .

\section{Stomach contents and degree of carnivory}

(Figs. 8 to 10 )

For all 4 predator species, copepod biomass in the stomach tended to increase with increased stomach fullness (Fig. 8). The highest stomach content of copepods showed a more or less linear increase with stomach fullness (Fig. 8A, C, E, G) although individual variability was always high, ranging down to zero for all 4 species and for all levels of stomach fullness. When the stomach content was expressed as a percentage of the body weight of the krill (Fig. 8B, D, F, H), part of the variability due to variable size of krill is eliminated. The displayed lines indicate the relationship between stomach 

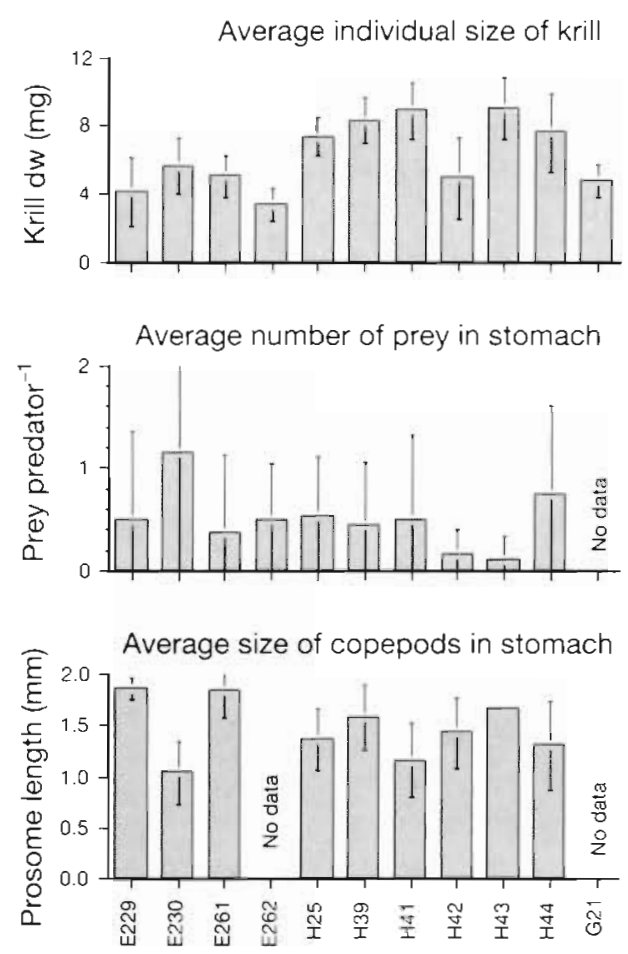
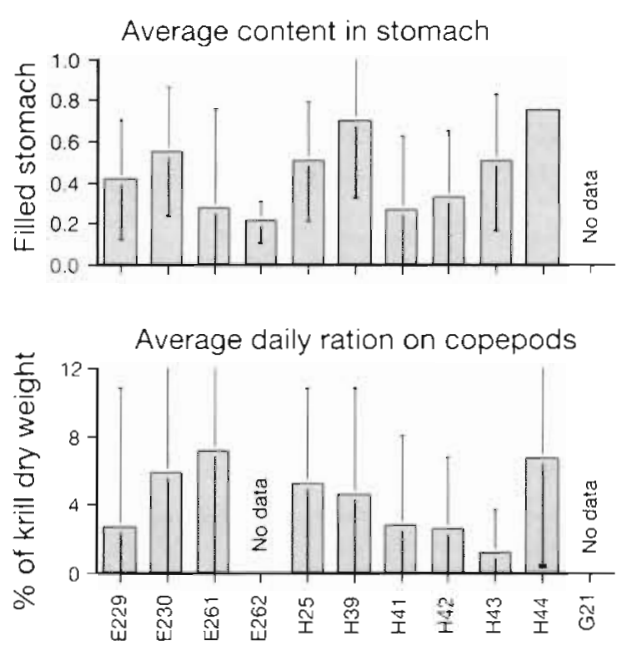

Fig. 6. Thysanoessa longicaudata. Average values of basic data related to the nutritional ecology of the species. See Fig. 4 for abbreviations
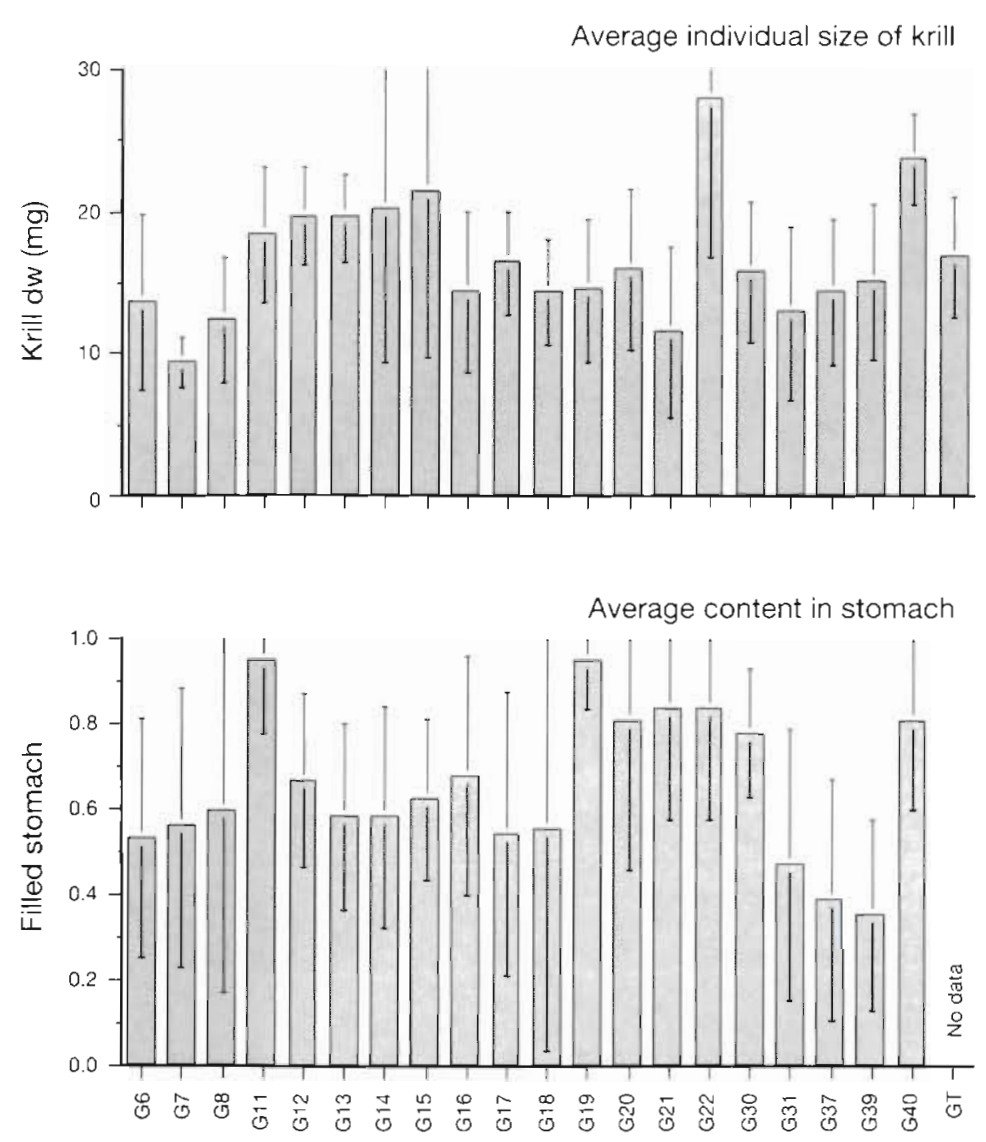

Fig. 7. Thysanoessa raschii. Average values of basic data related to the nutritional ecology of the species. See Fig. 4 for abbreviations fullness and weight of stomach content. They gave a similar relationship for Meganyctiphanes norvegica, Thysanoessa inermis and T. longicaudata, with a slope of 5.1,5.0 and 7.5 , respectively, whereas $T$. raschii diverged completely, showing a slope of 0.3 .

The total data on stomach content of copepod biomass, plotted against the individual dry weight of krill (Fig. 9), detected 2 trends. First, the number of krill without copepods in their stomach increased from Meganyctiphanes norvegica (13) to Thysanoessa inermis (39), T. longicaudata (55) and T. raschii (144), giving a decreasing proportion of respectively $93,69,35$ and $6 \%$ of krill feeding carnivorously. However, due to differences in size of the krill species, scores on carnivory for all krill except $M$. norvegica were probably underestimated. For example, T. longicaudata, the smallest species, can only take a few copepods per day. Even if feeding exclusively carnivorously on copepods, it will contain mandibles at the most during $D_{\mathrm{t}}$ - Nhours of the day, where $D_{\mathrm{t}}$ is the digestion time and $N$ is the number of prey eaten per day. Secondly, the data indicates a 10 - to 100 -fold variability in stomach content over the whole size spectrum of individual krill, and this variability overlaid any trend related to krill size. 


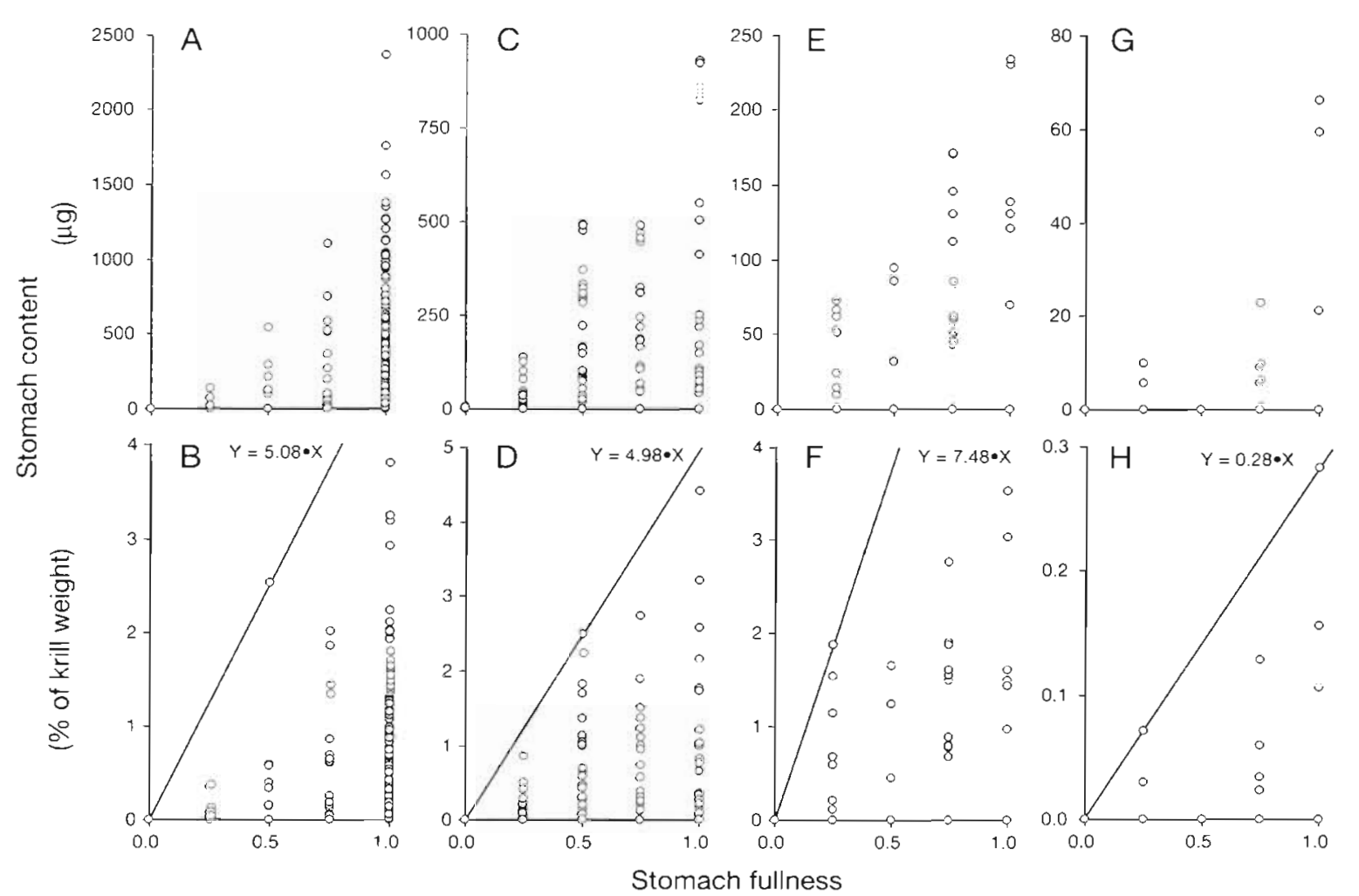

Fig. 8. Stomach content of copepod biomass in relation to stomach fullness (relative scale 0 to 1 ). (A, C, E, G) Actual biomass, $(B, D, F, H)$ stomach content as \% of the predator weight. Lines (with corresponding mathematical expression) show the estimated relative weight ( $\%$ of the predator weight) of stomach content as a function of fullness (see text for an explanation).

$(\mathrm{A}, \mathrm{B})$ Meganyctiphanes norvegica $(\mathrm{C}, \mathrm{D})$ Thysanoessa inermis; $(\mathrm{E}, \mathrm{F})$ T. longicaudata $(\mathrm{G}, \mathrm{H})$ T. raschii

The calculated percentage carnivory, based on the results of Fig. 8, showed that krill predation on copepods usually was less important in the southern area (Skagerrak) compared to the northern area (Fig. 10). Meganyctiphanes norvegica, with low stomach fullness, usually had a low degree of carnivory $(3$ to $15 \%)$, but with a higher fullness carnivory could reach $44 \%$. Thysanoessa inermis from the Skagerrak rarely fed carnivorously at all, but in the northern area the carnivory ranged from 8 to $35 \%$. T. longicaudata also showed low carnivory in the Skagerrak and only 2 of the 9 krill collected had copepods in their stomachs, making the statistics very poor. Carnivory from the northern area was usually in the range 10 to $30 \%$, with a maximum of $55 \%$, calculated for low stomach fullness. $T$. raschii were found with copepods in the stomach only a few times, irrespective of their usually high stomach fullness; therefore, copepods are not a major diet item of this species.

\section{Size of copepods in the stomach content \\ (Figs. 11 to 14 , Table 5)}

Calanus finmarchicus was by far the most common copepod prey for all species. Small females of Meganyctiphanes norvegica ( 5 to $7.5 \mathrm{~mm}$ carapace length) showed a negative skewed distribution in prey size of C. finmarchicus, with a peak distribution around

Table 5. Relative numeric relationship in occurrence (\% of all copepods) of different copepod prey in the water column and in stomach contents of Meganyctiphanes norvegica. Data from the 'G.O. Sars' cruise in the Skagerrak (cruise 3) sampled on 21 April 1991. Number of krill analysed = 14 (female) and 16 (male). Total number of copepods in stomach contents $=263$

\begin{tabular}{|lccccc|}
\hline Prey organism & \multicolumn{3}{c}{$\%$ in water column } & \multicolumn{2}{c|}{ \% in stomach contents } \\
& $0-15 \mathrm{~m}$ & $15-35 \mathrm{~m}$ & $35-110 \mathrm{~m}$ & Female & Male \\
\hline Calanus nauplii & 15 & 26 & 2.4 & 0 & 0 \\
Calanus copepodids & 4.7 & 58 & 45 & 66 & 85 \\
Temora longicornis & 4.1 & 4.1 & 0 & 12 & 3.3 \\
Acartia spp. & 1.2 & 4.1 & 1.6 & 13 & 0.8 \\
Pseudocalanus spp. & 26 & 2.1 & 4.0 & 1.4 & 1.6 \\
Others & 6.6 & 6.2 & 47 & 7.6 & 9.3 \\
Sum & 100 & 100 & 100 & 100 & 100 \\
\hline
\end{tabular}




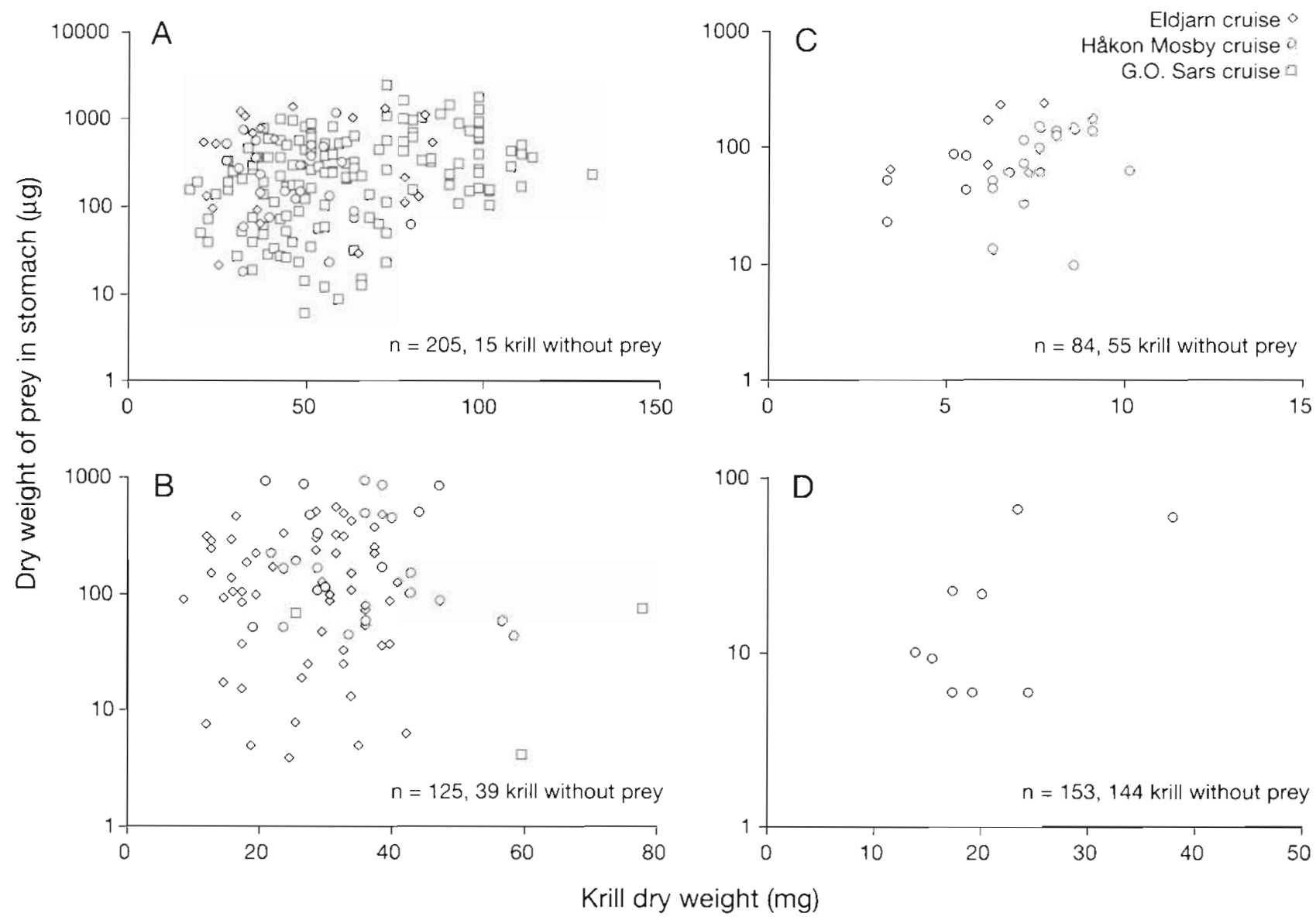

Fig. 9. Stomach contents of copepods in relation to krill body weight. (A) Meganyctiphanes norvegica; (B) Thysanoessa inermis; (C) T. longicaudata; (D) T. raschii. Number of analysed krill and krill without prey are displayed in each panel

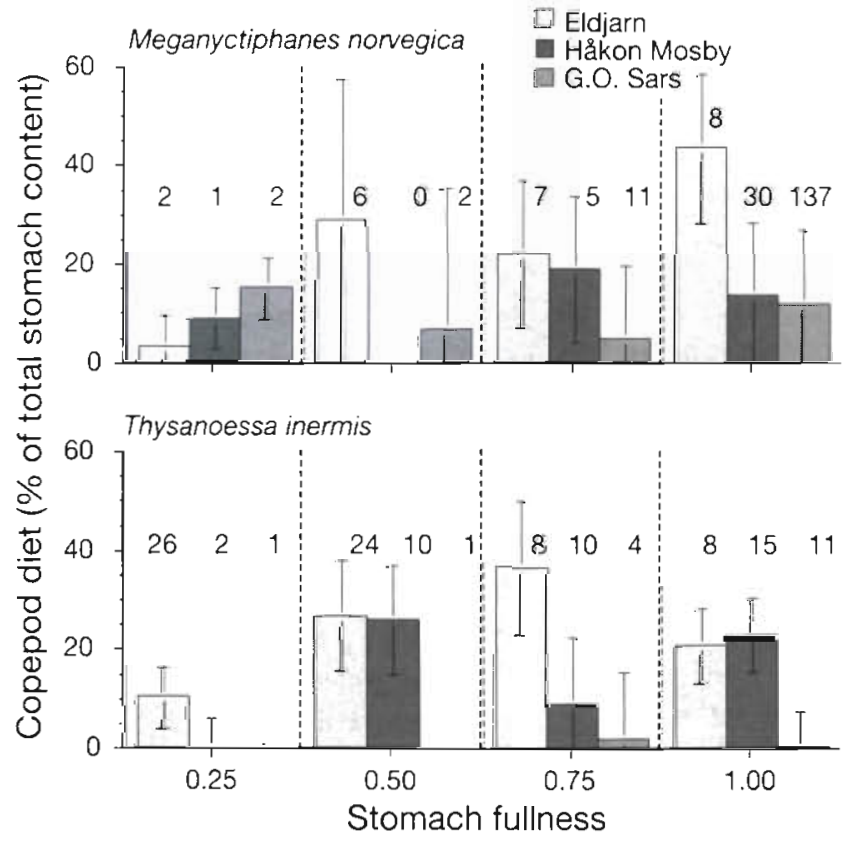

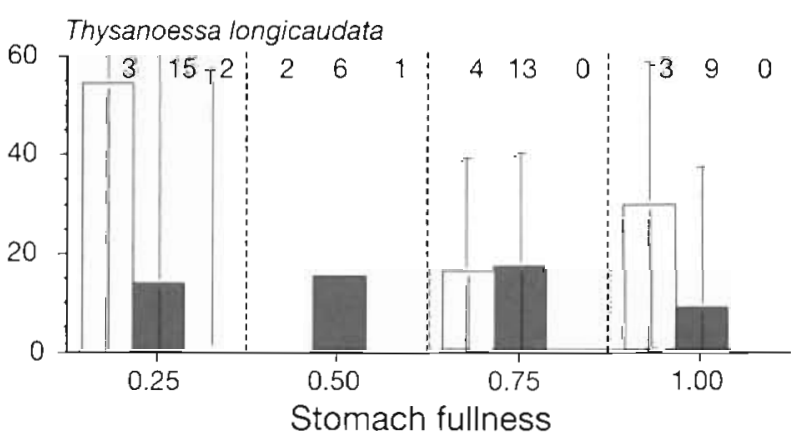

Fig. 10. Calculated average proportion of copepods in the diet of 3 krill species. The 4 different degrees of fullness are separately displayed and the numbers of analysed krill are given above each bar. Vertical thin lines denote $95 \%$ confidence limits 

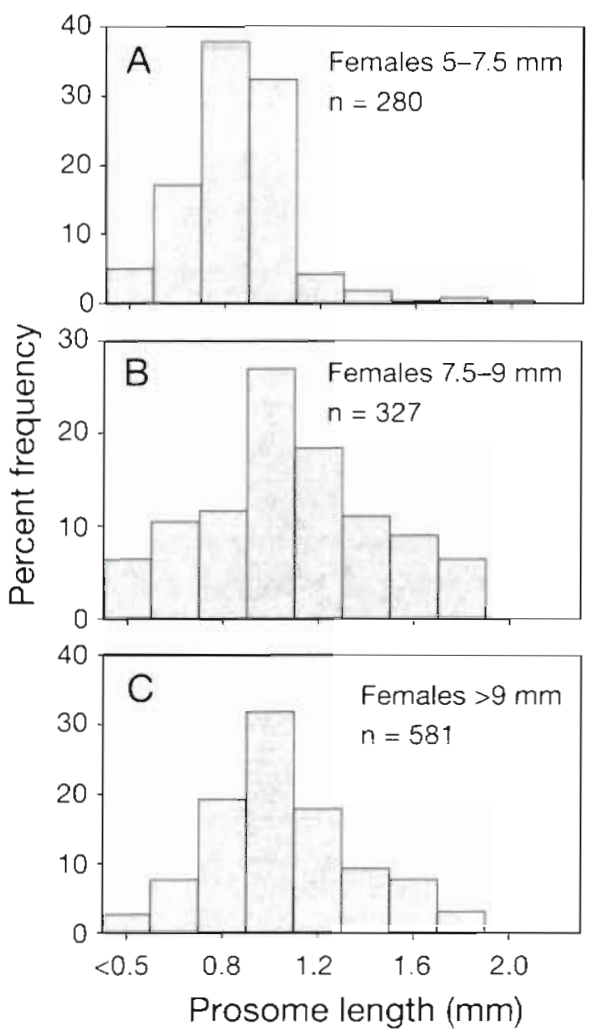

Fig. 11 Meganyctiphanes norvegica, females. Size distribution of the prey Calanus finmarchicus eaten by krill of 3 size classes (A to C). Data compiled from all 3 cruises. n: number of analysed mandibles

$0.8 \mathrm{~mm}$ prosome length (Fig. 11A), corresponding to stage II copepodids (Karlson \& Båmstedt 1994). The 2 larger predator size classes showed a normal distribution in consumed prey size, with peak abundance in C. finmarchicus size corresponding to stage III copepodids (Fig 11B, C).

Male Meganyctiphanes norvegica showed a size distribution for Calanus finmarchicus prey very similar to that of larger females (Fig. 12A-C), with peak abundance for all 3 size classes of krill around $1.0 \mathrm{~mm}$ prosome length. The total data for both sexes on the prey Metridia sp. indicated somewhat greater copepod size (Fig 12D), with peak abundance around $1.2 \mathrm{~mm}$ prosome length, and a positive skewness.

Other copepod species consumed by Meganyctiphanes norvegica were rather rare, and therefore the size distribution of these is less precise (Fig 13). The 3 defined species all showed an approximately normal distribution (Fig. 13A-C), with peak abundance of Temora longicornis at $0.45 \mathrm{~mm}$ prosome length, Pseudocalanus sp. and Acartia sp. both at $0.65 \mathrm{~mm}$ prosome length. The 2 latter species represent close to adult size, whereas the size of $T$. longicornis represents pre-adults (cf. Table 1 in Karlson \& Båmstedt 1994).
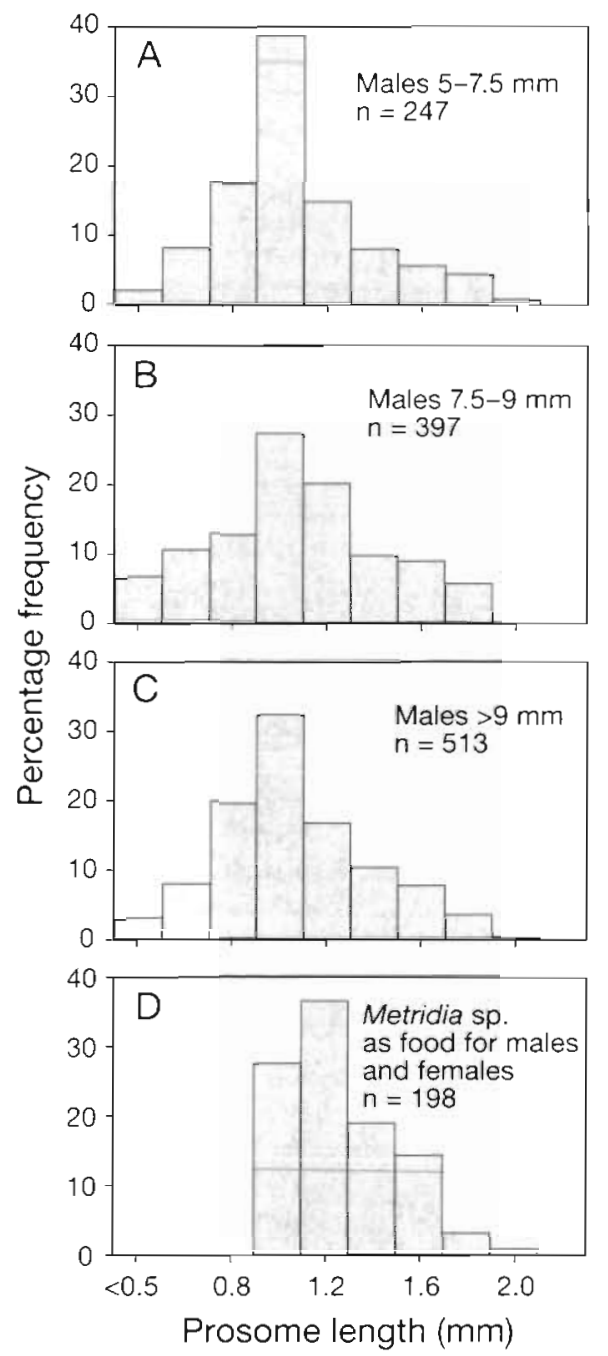

Fig. 12. Meganyctiphanes norvegica. Size distribution of (A to (.) Calanus finmarchicus eaten by males and (D) Metridia sp. eaten by both sexes of krill

The size distribution of unspecified copepods in the stomachs of Meganyctiphanes norvegica (Fig. 13D) showed a bimodal normal distribution, with peak abundance around 0.35 and $1.45 \mathrm{~mm}$ prosome length, respectively. The size of the small copepods fits well with the size of adult Oithona sp. (Karlson \& Båmstedt 1994) whereas the size of the larger ones is similar to that of late copepodids of Calanus finmarchicus, although they did not belong to this species.

Prey size distributions for Thysanoessa inermis and $T$. longicaudata are displayed in Fig 14. Only $T$. inermis preying on Calanus finmarchicus $(\mathrm{n}=586$ ) provided a high number and thereby reliable results. $T$ inermis showed a size preference similar to Meganyctiphanes norvegica, with peak abundance around $0.8 \mathrm{~mm}$ prosome length, but with the whole range of copepodid stages included in the diet. The relatively 

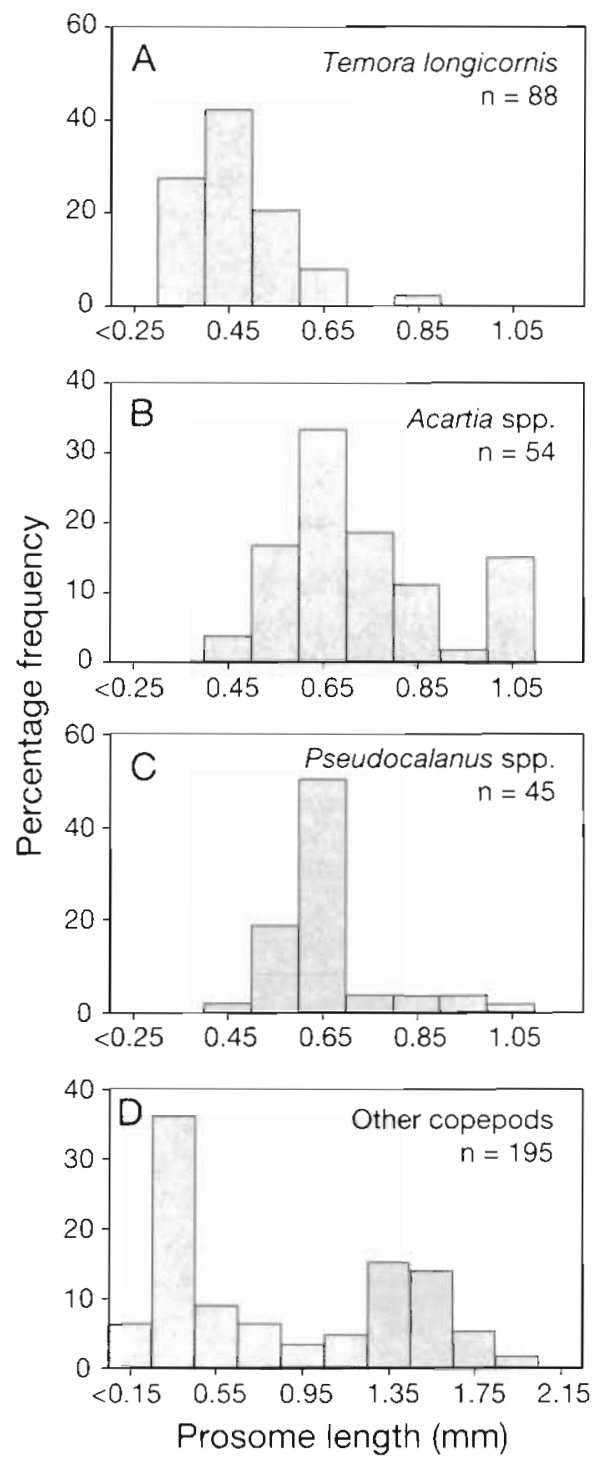

Fig. 13. Meganyctiphanes norvegica. Size distribution of copepod groups other than Calanus eaten by both sexes

high occurrence of copepod prey in the size class $2.6 \mathrm{~mm}$ is outside the size range for $C$. finmarchicus (Karlson \& Båmstedt 1994) and probably represents the closely related larger species $C$. hyperboreus.

Thysanoessa inermis showed a size distribution of the prey Metridia longa that indicated preference towards smaller copepodids compared to Meganyctiphanes norvegica (Fig. 14B), with peak abundance around 0.6 to $1.4 \mathrm{~mm}$. T. longicaudata took prey of Calanus finmarchicus in the same size range as did the other 2 krill species and peak abundance was in the range 0.6 to $1.8 \mathrm{~mm}$ prosome length (Fig. 14C).

A comparison of in situ abundance of the different prey species with the relative occurrence in the stomach contents of Meganyctiphanes norvegica is pro-

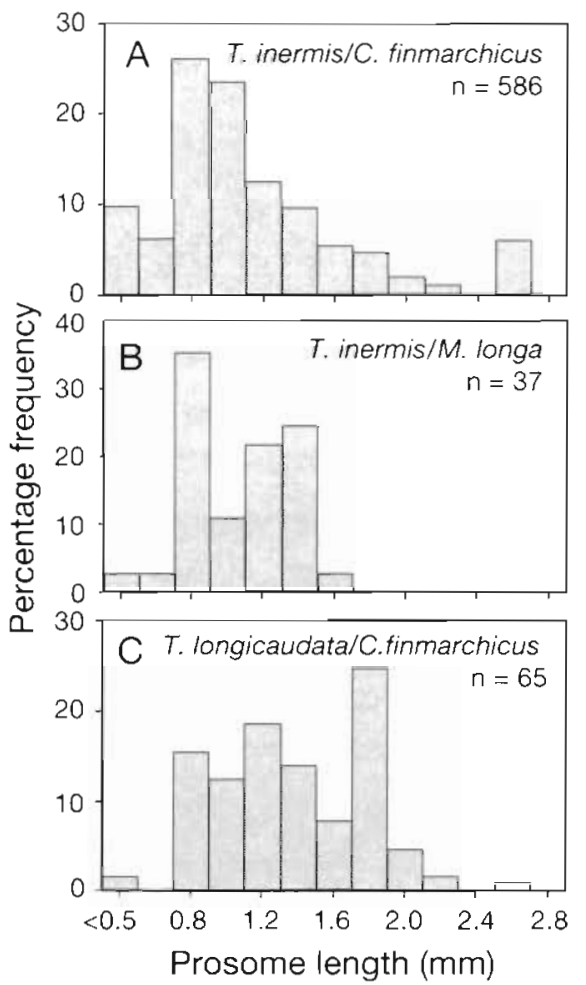

Fig. 14. Size distribution of (A) Calanus finmarchicus and (B) Metridia longa eaten by Thysanoessa inermis, and of (C) C. finmarchicus eaten by $T$. longicaudata

vided in Table 5. Zooplankton samples and predators were collected on 21 April 1991, but because different sampling gears and sampling depths were used there is no means of calculating an electivity index. However ${ }_{i}$ the trend is clear: a strong dominance of Calanus both in the water column and in the stomach contents. The fairly high abundance of Pseudocalanus spp. in the surface water ( 980 ind $\mathrm{m}^{-3}$ ) was not reflected in the stomach contents of $M$. norvegica.

\section{Interspecific comparisons (Tables $6 \& 7$ )}

A statistical interpretation of the predation characteristics is given in Table 6. A Student's t-test was used to determine differences at stations where at least $2 \mathrm{krill}$ species consumed copepods. This criterion restricts the data considerably, since relatively few stations gave multi-species krill samples. However, the data available indicated that Meganyctiphanes norvegica always had a higher copepod biomass in the stomach than Thysanoessa raschii and usually also higher than $T$. inermis, but the size of copepod eaten by the krill species was usually not different for the 4 species. Both degree of carnivory and daily ration gave the same indications as prey biomass, with the main difference found between $M$. nor- 
Table 6. Statistical evaluation (t-test) of differences between krill species in predation on copepods. Only stations with at least 2 species present are shown. Significance levels: $p<0.05, \cdots p<0.01, \cdots p<0.001$. ns: not significant

\begin{tabular}{|c|c|c|c|c|c|c|c|c|c|}
\hline Cruise & Stn & $\begin{array}{c}\text { No. analy } \\
\text { M.n. }\end{array}$ & $\begin{array}{c}\text { sed (no. } \\
\text { Ti. }\end{array}$ & $\begin{array}{c}\text { with } \mathrm{r} \\
\text { T.l. }\end{array}$ & $\begin{array}{c}\text { Iandibles) } \\
\text { T.r. }\end{array}$ & Prey biomass & Prey size & $\begin{array}{l}\text { Degree of } \\
\text { carnivory }\end{array}$ & Daily ration \\
\hline Eldjarn & $\begin{array}{l}\text { E229 } \\
\text { E230 } \\
\text { E251 }\end{array}$ & $6(6)$ & $\begin{array}{c}9(3) \\
9(3) \\
11(11)\end{array}$ & $\begin{array}{l}9(1) \\
9(4)\end{array}$ & & $\begin{array}{c}\text { ns } \\
\text { ns } \\
M n>\operatorname{Ti} \cdots\end{array}$ & $\begin{array}{l}\text { ns } \\
\text { ns } \\
\text { ns }\end{array}$ & $\begin{array}{c}\mathrm{ns} \\
\mathrm{Ti}<\mathrm{Tl} . \\
\mathrm{Mn}>\mathrm{Ti} .\end{array}$ & $\begin{array}{c}\text { ns } \\
\mathrm{Ti}<\mathrm{Tl}^{*} \\
\mathrm{Mn}>\mathrm{Ti}^{\cdots}\end{array}$ \\
\hline H. Mosby & $\begin{array}{l}\mathrm{H} 17 \\
\mathrm{H} 39 \\
\mathrm{H} 44\end{array}$ & $\begin{array}{l}8(8) \\
9(8)\end{array}$ & $\begin{array}{l}5(5) \\
6(3)\end{array}$ & $\begin{array}{l}8(3) \\
4(3)\end{array}$ & & $\begin{array}{l}\text { ns } \\
\text { ns } \\
\text { ns }\end{array}$ & $\begin{array}{c}\mathrm{Mn}<\mathrm{Ti} \cdot \\
\mathrm{Mn}<\mathrm{Tl} \cdot \cdot \\
\text { ns }\end{array}$ & $\begin{array}{l}\text { ns } \\
\text { ns } \\
\text { ns }\end{array}$ & $\begin{array}{c}\text { ns } \\
\text { ns } \\
\mathrm{Ti}<\mathrm{TI}\end{array}$ \\
\hline G.O. Sars & $\begin{array}{l}\text { G6 } \\
\text { G7 } \\
\text { G8 } \\
\text { G11 } \\
\text { G12 } \\
\text { G13 } \\
\text { G14 } \\
\text { G16 } \\
\text { G18 } \\
\text { G19 } \\
\text { G20 } \\
\text { G21 } \\
\text { G30 } \\
\text { G39 } \\
\text { G40 }\end{array}$ & $\begin{array}{l}9(7) \\
9(8) \\
9(8) \\
9(9) \\
9(9) \\
9(9) \\
9(9) \\
9(9) \\
9(9) \\
9(9) \\
9(7) \\
9(9) \\
9(9) \\
9(8) \\
9(7)\end{array}$ & $\begin{array}{l}2(0) \\
6(1)\end{array}$ & $9(0)$ & $\begin{array}{l}8(0) \\
9(0) \\
8(0) \\
9(0) \\
6(4) \\
9(2) \\
6(1) \\
7(0) \\
5(0) \\
9(1) \\
9(0) \\
6(0) \\
9(0) \\
5(0) \\
9(0)\end{array}$ & $\begin{array}{c}M n>\operatorname{Tr} \cdots \\
M n>\operatorname{Tr} \cdots \\
M n>\operatorname{Tr} \cdots \\
M n>\operatorname{Tr} \cdots \\
M n>\operatorname{Ti} \cdots>\operatorname{Tr} \cdots \\
M n>\operatorname{Tr} \cdots \\
M n>\operatorname{Ti} \cdots \operatorname{Tr} \cdots \\
M n>\operatorname{Tr} \cdots \\
M n>\operatorname{Tr} \cdots \\
M n>\operatorname{Tr} \cdots \\
M n>\operatorname{Tr} \cdots \\
M n>\operatorname{Ti}, \operatorname{Tr}, \operatorname{Tr} \cdots \\
M n>\operatorname{Tr} \cdots \\
M n>\operatorname{Tr} \cdots \\
M n>\operatorname{Tr} \cdots\end{array}$ & $\begin{array}{c}\mathrm{Mn}>\operatorname{Tr} \\
\text { ns } \\
\text { ns }\end{array}$ & $\begin{array}{c}M n>\operatorname{Tr} \cdots \\
M n>\operatorname{Tr} \cdots \\
M n>\operatorname{Tr} \cdots \\
M n>\operatorname{Tr} \cdots \\
M n=\operatorname{Tr}>\operatorname{Ti} \cdots \\
M n>\operatorname{Tr} \cdots \\
M n>\operatorname{Ti} \cdots \operatorname{Tr} \cdots \\
M n>\operatorname{Tr} \cdots \\
M n>\operatorname{Tr} \cdots \\
M n>\operatorname{Tr} \cdots \\
M n>\operatorname{Tr} \cdots \\
M n>\operatorname{Ti} \operatorname{Tr}, \cdots \\
M n>\operatorname{Tr} \cdots \\
M n>\operatorname{Tr} \cdots \\
M n>\operatorname{Tr} \cdots\end{array}$ & $\begin{array}{c}M n>\operatorname{Tr} \cdots \\
M n>\operatorname{Tr} \cdots \\
M n>\operatorname{Tr} \cdots \\
M n>\operatorname{Tr} \cdots \\
M n>\operatorname{Tr} \cdots>\operatorname{Ti} \cdots \\
M n>\operatorname{Tr} \cdots \\
M n>\operatorname{Ti} \cdots \operatorname{Tr} \cdots \\
M n>\operatorname{Tr} \cdots \\
M n>\operatorname{Tr} \cdots \\
M n>\operatorname{Tr} \cdots \\
M n>\operatorname{Tr} \cdots \\
M n>\operatorname{Ti}, \operatorname{Ti} \operatorname{Tr}^{\prime} \cdots \\
M n>\operatorname{Tr} \cdots \\
M n>\operatorname{Tr} \cdots \\
M n>\operatorname{Tr} \cdots\end{array}$ \\
\hline
\end{tabular}

vegica and $T$. raschii (Table 6 ). If we do not restrict the comparisons to species from the same stations the results of the statistical comparisons are clearer (Table 7). These results showed a ranking in prey biomass: M.n. > T.i. > T.1. > T.r., of copepod size: T.l. > M.n. > T.i. > T.r., of degree of carnivory: M.n. =T.i. =T.l.>T.r., but M.n. $>$ T.l., and of daily ration for copepod prey: M.n. $=$ T.i. $>$ T.l. $>$ T.r.

\section{Predation characteristics of Meganyctiphanes norvegica in the field (Figs. 15-17)}

The field data gave a total range in predation rate from zero to 10 copepods ind.$^{-1} \mathrm{~h}^{-1}$ and a corresponding daily ration from zero to $125 \%$ (Fig. 15). Neither

Table 7 . Statistical evaluation ( $t$-test) of differences between krill species in predation on copepods. Material from all cruises has been compiled. Significance levels: $p<0.05, \cdots p$ $<0.01, \cdots p<0.001$. Mn: Meganyctiphanes norvegica $(n=$ 205,190 with copepods); Ti: $T$. inermis ( $\mathrm{n}=125,86$ with copepods); Tl: T. Longicaudata ( $\mathrm{n}=84,29$ with copepods); Tr: $T$ raschij ( $\mathrm{n}=153,9$ with copepods)

\begin{tabular}{|c|c|c|c|}
\hline $\begin{array}{l}\text { Copepod } \\
\text { biomass }\end{array}$ & $\begin{array}{l}\text { Copepod } \\
\text { size }\end{array}$ & $\begin{array}{l}\text { Degree of } \\
\text { carnivory }\end{array}$ & $\begin{array}{l}\text { Daily } \\
\text { ration }\end{array}$ \\
\hline$M n>T_{i} \cdots$ & $\mathrm{Mn}>\mathrm{Ti}^{-}$ & $\mathrm{Mn}=\mathrm{Ti}$ & $\mathrm{Mn}=\mathrm{Ti}$ \\
\hline $\mathrm{Mn}>\mathrm{Tl} \cdots$ & $\mathrm{Mn}<\mathrm{Tl}$ & $\mathrm{Mn}>\pi^{*}$ & $\mathrm{Mn}>\mathrm{T} \cdots$ \\
\hline$M n>\operatorname{Tr} \cdots$ & $M n>\operatorname{Tr} \cdots$ & $M n>\operatorname{Tr} \cdots$ & $M n>\operatorname{Tr} \cdots$ \\
\hline $\mathrm{Ti}>\mathrm{Tl} \cdots$ & $\mathrm{Ti}<\mathrm{Tl} \cdots$ & $\mathrm{Ti}=\mathrm{Tl}$ & $\mathrm{Ti}>\mathrm{Tl} \cdot \cdot$ \\
\hline $\operatorname{Ti}>\operatorname{Tr} \cdots$ & $\mathrm{T}_{i}>\mathrm{Tr}$ & $\mathrm{Ti}>\mathrm{Tr} \cdots$ & $\operatorname{Ti}>\operatorname{Tr} \cdots$ \\
\hline$\Pi l>\operatorname{Tr} \cdots$ & $\operatorname{TI}>\operatorname{Tr} \cdots$ & T] $>\operatorname{Tr} \cdots$ & $\mathrm{Tl}>\operatorname{Tr} \cdots$ \\
\hline
\end{tabular}

expressions showed any tendency of a significant relationship with the body weight of the predator.

The total dominance of Calanus finmarchicus in the diet of Meganyctiphanes norvegica is illustrated in Figs. 16 \& 17. Most commonly $100 \%$ of the daily ration was composed of this species and only when the daily ration was relatively low did the dominance of $C$. finmarchicus go down below $90 \%$ (Fig. 16).

The species distribution (biomass proportion) of copepod prey for 4 size classes of Meganyctiphanes norvegica is given in Fig. 17. Although Calanus finmarchicus was always dominant, the results indicate an increase from $85 \%$ for the smallest krill to $93-95 \%$ for those above $50 \mathrm{mg}$ dry weight. Acartia sp. also made up a significant proportion, ranging from 2 to almost $10 \%$, whereas Temora longicornis was the third most dominant species, accounting for $5 \%$ for krill in the size range 80 to $110 \mathrm{mg}$ dry weight.

\section{DISCUSSION}

This investigation is the first to specifically show quantitative differences in trophic position among the dominating euphausiid species in the Northeast Atlantic. Our experimental results on predation rate of Meganyctiphanes norvegica agree with the estimated field rates, and thereby strengthen our conclusions about the trophic relationships in the field. The method we used to quantitatively determine the degree of carnivory is new, so its limitations need to be discussed. 

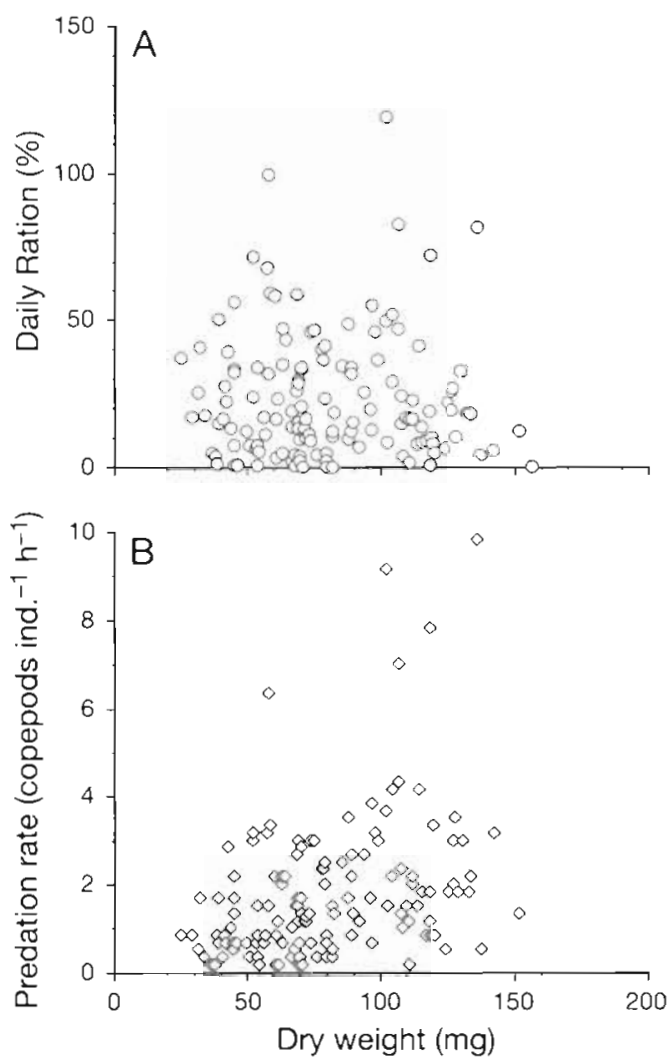

Fig. 15. Meganyctiphanes norvegica. (A) Daily ration and (B) predation rate of krill sampled during the field cruises. Due to overlapping not all points are visible

\section{Trophic relationship between copepods and krill}

Earlier studies suggested trophic differences among the 4 krill species. Falk-Petersen et al. (1981) and Sargent \& Falk-Petersen (1981) showed differences in

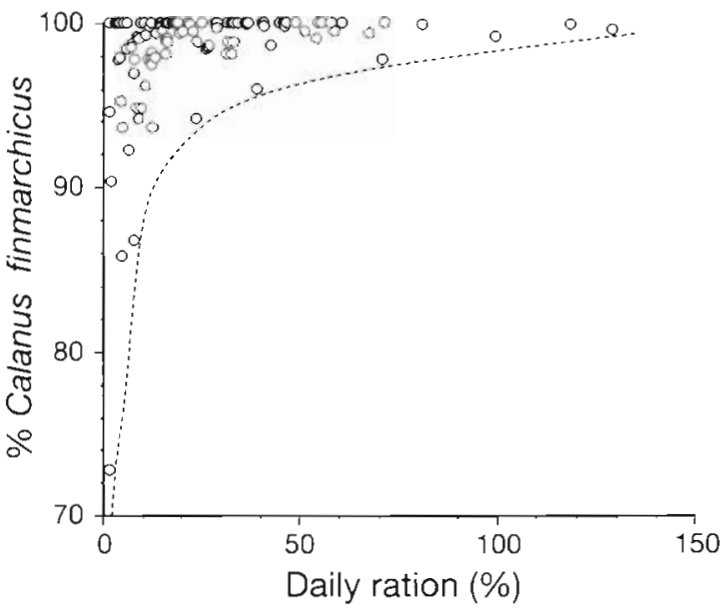

Fig. 16. Meganyctiphanes norvegica. Proportion of the diet of copepods belonging to the species Calanus finmarchicus, plotted against the daily ration. Data from cruise 3 with RV 'G.O. Sars' in the Skagerrak, 1991 the seasonal changes in lipid classes and fatty-acid composition between Meganyctiphanes norvegica, Thysanoessa inermis and $T$. raschii found in northern Norway. These differences were attributed to feeding habits; $T$. inermis and especially $T$. raschii showed high occurrence of phytyl esters, indicating detritivory on food of plant origin. Fevolden (1982) showed that $M$. norvegica had a greater heterozygosity for gene loci coding for digestion enzymes than $T$. raschii, indicating a more varied diet for the former species in Oslofjorden, southern Norway, and Artiges et al. (1978) showed that the shape of the mandibles of $M$. norvegica, with a sharp pars inciva and a keen edge, indicated an adaptation to carnivorous feeding. Direct studies of the stomach contents of the 3 species in spring and autumn/winter were conducted in the Gulf of St. Lawrence by Sameoto (1980), showing that 90 and $100 \%$, respectively, of the andlysed $M$. norvegica had copepod remains in the 2 seasons, whereas 22 and $25 \%$ of $T$. inermis and 5 and $25 \%$ of $T$. raschil contained copepods. Thus, all these earlier studies indicate the same rank in carnivory for the 3 species as shown in our more quantitative study. In addition, the laboratory study by McClatchie (1985) also indicated that $M$. norvegica cannot survive on a pure phytoplankton diet, but needs large copepods in high abundance. His results indicated a necessary abundance of Calanus finmarchicus of $>19$ copepods $1^{-1}$ to meet its metabolic demands of $4.6 \%$ of krill body energy $\mathrm{d}^{-1}$, and he concluded that $M$. norvegica is adapted to exploit dense food patches or layers. An ability to detect and remain in such food aggregations has been experimentally shown for $T$. raschii kept in a large tank with a dense phytoplankton patch (Price 1989). Although McClatchie's (1985) conclusion that large copepods are

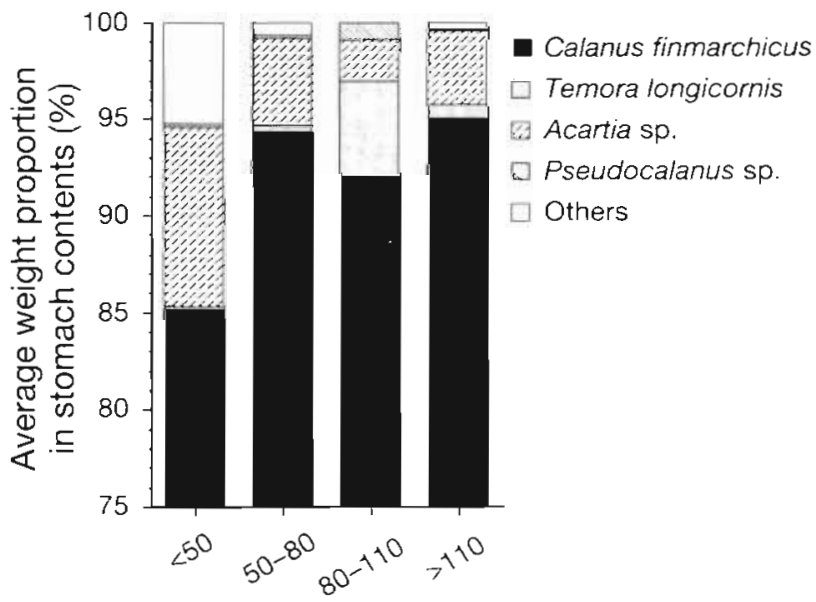

Size class (mg dry weight)

Fig. 17. Meganyctiphanes norvegica. Species composition of the diet of copepods in krill of 4 different size classes. Data from cruise 3 with RV 'G.O. Sars' in the Skagerrak, 1991 
an important food source was probably right, the extremely high prey abundance needed for maintenance was probably not; the small volume $(4 \mathrm{l})$ of the experimental jars probably suppressed predation (cf. Price et al. 1988) and our experiments in 45 or 90 l tanks with 1.2 to 2 prey ${ }^{-1}$ (see Table 1 ) usually gave daily rations exceeding $10 \%$. The same critique can be made of Stuart's (1986) experiments with Euphausia lucens in 0.51 jars, where a concentration of 156 copepods $1^{-1}$ was needed to balance the metabolic requirements.

Prey capture is the product of the encounter rate and the susceptibility of a prey to a specific predator, the former a function of swimming rate and direction of prey and predator and detection distance (Gerritsen \& Strickler 1977), with turbulence as a physical phenomenon adding a positive term to the swimming rate (Rotschild \& Osborn 1988). Larger prey (higher swimming rate, earlier detection) should be preyed upon more often than small prey. However, the susceptibility, defined as the proportion of encounters leading to prey consumption, may counteract through a higher escape ability of larger prey (Greene 1986). Preference for small copepods was shown for Euphausia hanseni (average $0.39 \mathrm{~mm}$ prosome length of prey) and Nematoscelis megalops $(0.49 \mathrm{~mm})$ by Barange et al. (1991) in a field study from the northern Benguela upwelling system and for E. lucens from South African coastal waters by Gibbons et al. (1991b), where the copepod size class $<0.45 \mathrm{~mm}$ prosome length was over-represented in the stomach contents. Although both studies showed a broad selection of prey sizes, the significant selectivity towards smaller prey was explained by the low ability of small organisms to withstand the negative pressure caused by the feeding beats from the filtering basket of the predator. Stuart \& Hugget (1992) also found highest selectivity on small, slowly moving prey from their laboratory experiments with E. lucens, but of specific interest to our own results, they also found that stage II copepodids were the most selected developmental stage of Calanus agulhensis, a species similar in size to C. finmarchicus, and almost no older developmental stages than copepodids III were caught. This was explained as a combination of prey size and swimming speed, optimised at stage II copepodids. Our data for the smallest Meganyctiphanes norvegica females indicated a similar abrupt decrease in occurrence of Calanus prey above stage II/III copepodids (Fig. 11.A), but not so for larger females or any of the size classes of males (cf. Figs. 11B, C \& 12). Neither did Thysanoessa inermis or $T$. longicaudata show any size threshold for $C$. finmarchicus prey (cf. Fig. 14A, C), indicating that none of the $3 \mathrm{krill}$ species was heavily restricted in its prey capture by different escape ability of the developmental stages of $C$. finmarchicus.
Although predation on copepods was substantial for 3 of the 4 species investigated in the present study, none of them showed (on average) a dominance of carnivory. Thus, based on the average values for highest stomach fullness (1.00) of the krill species from the 3 cruises (see Fig. 10) Meganyctiphanes norvegica fed carnivorously to $23 \%$, Thysanoessa inermis to $15 \%$ and $T$. longicaudata to $19 \%$. A dominance of nonanimal food has also been indicated in the few earlier quantitative studies where herbivory and carnivory were simultaneously determined. Thus Euphausia superba could get less than $10 \%$ of its minimum metabolic requirement from copepod prey at ambient concentrations (Price et al. 1988) and E. pacifica showed a daily ration on the copepod Pseudocalanus sp. of only $0.45 \%$ on a carbon basis, compared to $8.8 \%$ on a phytoplankton diet (Ohman 1984). However, E. lucens adults showed a predominance of carnivory, but herbivory dominated among juveniles (Stuart \& Pillar 1990). This species also showed a switching tendency towards more carnivory when phytoplankton availability was low.

The impact of krill predation is a function of the abundance of both prey and predator and the average predation rate. A precise estimate of the abundance of krill species is difficult to determine because of their extensive vertical migration, often species-specific (Kulka et al. 1982), their ability to escape from plankton nets (Sameoto et al. 1993) and their swarming behaviour (Nicol 1986). Estimates based on net abundance data on prey and predator will thus underestimate the latter and thereby also underestimate both abundances and predation impact. Without taking into account this potential bias, we have calculated the predation impact of Meganyctiphanes norvegica from Kosterfjorden on the Swedish Skagerrak coast. Here it has an annual biomass ranging from zero to ca $1600 \mathrm{mg}$ DW $\mathrm{m}^{-2}$, and its main prey, Calanus finmarchicus, has a corresponding biomass from 1000 to $12000 \mathrm{mg} \mathrm{DW}$ $\mathrm{m}^{-2}$, with ca $5000 \mathrm{mg} \mathrm{DW} \mathrm{m^{-2 }}$ in August-September, when maximum krill biomass was reported (Bamstedt 1988). Our field results showed average daily rations on copepods in the range 1 to $20 \%$ of the predator dry weight (see Fig. 4), i.e. 16 to $320 \mathrm{mg}$ prey DW d ${ }^{-1}$, corresponding to a reduction of $C$. finmarchicus biomass by 0.3 to $6.4 \%$ daily. Our results showed that the average degree of carnivory was $40 \%$ or less, and it is supposed that the degree of carnivory is inversely related to the phytoplankton abundance (Stuart \& Pillar 1990). Thus, the overwintering period of $C$. finmarchicus, with low phytoplankton occurrence and with no recruitment, may represent the period of highest potential impact. Unpublished results from Kosterfjorden show that $C$. finmarchicus has adapted an overwinter ing strategy with 6 mo of low activity in the deep water. 
and the possibility of a impact from krill predation is therefore obvious. However, it remains to be shown that the 2 species co-occur in the same part of the water column during this period and also have established a predator-prey relationship.

\section{Degree of carnivory-a methodological evaluation}

There are 9 sources of error that may cause bias or weaken the precision of the method. (1) A sampling time of $>30$ min may reach or even exceed the digestion time of the predator (cf. 15 to 30 min. for Meganyctiphanes norvegica with Artemia as food, Heyraud 1979). (2) A fixed digestion time may not be valid in the calculations. (3) The predators may feed in the sampling gear (cf. Nicol 1984). (4) Calculations from copepod mandible size to copepod body mass may be biased (cf. Karlson \& Båmstedt 1994). (5) Stomach fullness is not a precise expression. (6) The maximum $Y / X$ ratio defined from the material (see text earlier and Fig. 8) may not represent a pure copepod diet, i.e. the real maximum $Y / X$ ratio is underestimated. (7) Incomplete ingestion of prey may bias the estimates. (8) Extrapolation to a full day period from stomach content representing the last hour(s) of feeding may be uncertain. (9) Variation in krill feeding behaviour on a diel as well as seasonal basis will cause variability.

(1) Our estimates of digestion times greatly exceeded those of Heyraud (1979) and were more in line with those found for scyphozoan jellyfishes from Norwegian coastal waters preying on Calanus finmarchicus (Martinussen \& Bamstedt in press). The stomach fullness was usually also high in our material, indicating little reduction in stomach content. And finally, only the stomach content, but not the relative proportion of copepods in relation to other food, should be affected by the digestion, as long as the digestion rate is the same for all food items. This factor will therefore not have any effects on the degree of carnivory, but will tend to underestimate the predation rate.

(2) It is well known that the gut residence time may be highly variable, especially as an effect of feeding intensity (cf. Murtaugh 1984) and this parameter should therefore not be evaluated from experiments with pre-feeding animals held in starving conditions. Our method of estimating the digestion time is based on krill continuously feeding, thus making it less sensitive to such effects.

(3) Food within the cod end of the sampling gear may easily be entrapped in the feeding basket of the krill, and quantification of feeding from contents of the feeding basket is therefore not advisable (Nicol 1984). However, Baier \& Purcell (1997) reported that loss rather than increase in gut contents was the main problem when sampling chaetognaths, and therefore recommended tows with very short duration. If a nonfiltering cod end is used, it is more likely that the krill also ingest the food, compared to a filtering cod end, and therefore food in the foregut should not be used in the quantification. Furthermore, since the sampling gear aggregates a highly selective size fraction of organisms, any ingestion from cod end contents will give biased results both in predation rate (increased) and food selectivity. We used a filtering cod end in our samplings, and in the northern area the mesh size of the trawl was so large that copepods were eliminated in the catches. In the Skagerrak (cruise 3) copepods were caught together with the krill, but occurrence in the stomach content was considerably lower than in the northern area, indicating this factor to be of little importance.

(4) A seasonal variation in length/weight relationships is to be expected in copepods, especially for high-latitude species that face a strong seasonal change in food supply. Using a single length/weight relationship throughout the year for Calanus finmarchicus may cause an error of up to $90 \%$ (Karlson \& Båmstedt 1994), but such high errors are only related to the end of the overwintering period, when the body reserves are exhausted. More typical errors are below $20 \%$ (Karlson \& Båmstedt 1994). With the strong dominance of $C$. finmarchicus found in our investigation, conversion from mandible width to body mass of prey using a species-specific relationship should be very precise. In contrast, a more divergent prey assemblage and the use of a single general conversion equation would result in higher variability. A general relationship was used by Stuart \& Pillar (1990), and especially for predators that contain only 1 or a few copepod specimens in the stomach, i.e. relatively small krill species like Euphausia lucens in their studies, the bias may be substantial. Karlson \& Båmstedt (1994) showed that a general equation applied to individuals of Temora longicornis overestimated the body mass by up to 4 times, although this species was the only one investigated that diverged markedly from the general mandible-size/dry-weight relationship.

(5) The stomach fullness was subjectively determined in our study, using a rough scale. This will lower the precision in the estimate but will probably not cause a bias, because over- and underestimates of stomach fullness are equally likely to occur. An alternative to stomach fullness would have been to weigh the prepared stomach and express the degree of carnivory as the weight proportion of copepods, but this would be a more laborious method, also adding an additional source of error through the preparation and weighing of the stomachs. Measurements of chlorophyll derivatives in the stomach and relationship be- 
tween calculated algal mass and copepod mass should give information on copepod versus algal food only, and hence would tend to overestimate the degree of carnivory. However, this method has been previously used with success by Stuart \& Pillar (1990) and Gibbons (1993) for partitioning between krill herbivory and carnivory.

(6) If the maximum $Y / X$ ratio observed in the sample (see 'Material and methods') actually represents both copepods and other food items, a systematic overestimation of the degree of carnivory will occur. However, with large sets of data such as those used for Meganyctiphanes norvegica, Thysanoessa inermis and $T$. longicaudata, this bias will be minor. Our results for the 3 most carnivorous species resulted in similar expressions, showing that the content of a full stomach amounted to $5.0 \%$ ( $M$. norvegica), $5.1 \%$ ( $T$. inermis) and $7.5 \%$ ( $T$. longicaudata) of the weight of the krill (cf. Fig. 8). These figures can be used in future calculations of degree of carnivory based on stomach fullness and copepod prey mass. Previous weighing of dissected stomachs of $M$. norvegica females, 8 to $9 \mathrm{~mm}$ carapace length, with different fullness (Nicol 1984), yielded a variation from ca $180 \mu \mathrm{g}$ dry weight (0 to $25 \%$ fullness) to ca $420 \mu \mathrm{g}$ (75 to $100 \%$ fullness). If these data are used in a linear regression analysis, they indicate that the content of a full stomach is ca $300 \mu \mathrm{g}$. This corresponds to $5-6 \%$ of the body dry weight, i.e. almost identical to our calculations. Thus, the close similarity between $M$. norvegica, $T$. inermis and $T$. longicaudata and the very close estimate from the independent study are strong indications of the suitability of the method.

(7) Beyer (1993) reported a high occurrence of damaged Calanus finmarchicus in plankton samples from Oslofjorden, Norway, and also found the same type of injured copepods in the feeding baskets of Meganyctiphanes norvegica. Without being able to give any quantitative evaluation of this, he concluded that $M$. norvegica probably tears apart its prey and often leaves parts of it uneaten. Our laboratory experiments (Fig. 3) showed that this commonly occurs, but for ca $80 \%$ of the prey ingestions the whole prey was consumed. Furthermore, the bias due to partly eaten prey seems to be negligible, because there is no clear trend of selection toward the anterior or posterior part of the prey body. Ohman (1984) recorded a $22 \%$ occurrence of injured Pseudocalanus sp. in predation experiments with Euphausia pacifica, but in contrast to our results for $M$. norvegica, only minor parts, such as the antennules, swimming legs and urosome, were missing. However, Pseudocalanus sp. was a sub-optimal food for E. pacifica, giving a maximum daily ration of only $0.45 \%$, whereas $C$. finmarchicus certainly is a preferred prey for $M$. norvegica. Price et al. (1988) recorded $0.66 \%$ occurrence of injured prey copepods (Metridia gerlachei) from experiments with E. superba, and similar to our results, no clear trend of selecting the front or back part of the prey. Thus, the similarities in the results from 3 independent studies support the statement that prey damage will not cause a bias in the method.

(8) If the predation rate of a predator is variable over time, the stomach content will also show variability, and any extrapolation to daily prey intake from the stomach content at a single point in time may be misleading. However, by spreading sampling over time, there is no bias involved, because the probability of over- and underestimates is the same. Thus, the method will tend to exaggerate the individual variability and thereby reduce the precision, making statistical conclusions more uncertain. This logic also holds for the relative proportion of copepods and other food, i.e. the degree of carnivory.

(9) The method of analysing the stomach content of krill restricts the interpretation of the results to a period of a few hours prior to the sampling. Phytoplankton food is mainly restricted to the upper few tens of meters over the full day, whereas copepods and euphausiids may vary their vertical distribution on a diurnal basis (Mauchline 1980, Sameoto 1980, Simmard et al. 1986). Thus, the ambient food source available for the predator is probably continuously varying and sampling at different depths and at different times may indicate strong changes in the diet. Prey selectivity can therefore only be interpreted from distribution data of predators and prey and using a sampling design where both the vertical migration and the digestion time are taken into consideration (cf. Gibbons et al. 1991a). Determining prey selection was not an initial aim in this study, but the material from the northern area (cruises 1 and 2) did indicate a higher daily ration on copepods for Meganyctiphanes norvegica collected at night compared to those collected in the daytime (see earlier), and out of 6 stations where $M$. norvegica occurred, 5 were from the night and showed higher predation on copepods than the single one from the daytime (cf. Fig. 4, Table 1). However, no such trends could be detected for Thysanoessa inermis and T. Iongicaudata (cf. Table 4). The results by Sameoto (1980) indicated that $M$. norvegica fed mainly on copepods during the day and on both copepods and phytoplankton during the night when they had migrated above $75 \mathrm{~m}$ depth. $T$. inermis and $T$. raschii fed mainly during the night, above $75 \mathrm{~m}$ depth and primarily on phytoplankton. Thus, previous knowledge of the biology of the investigated species is important when designing a field investigation studying trophic dynamics of omnivorous organisms. 
Acknowledgements. We thank the Institute of Marine Research, Bergen, for the opportunity to join the research cruises with RV 'Eldjarn' and 'G.O. Sars' We also thank the former Nordic Council for Marine Biology for a scholarship to K.K. Scientific critique and valuable linguistic suggestions were kindly given by Karla Heidelberg, HPEL, Univ. Maryland, USA, and 3 referees provided constructive critique

\section{LITERATURE CITED}

Artiges JM, Pagano M, Thiriot A. (1978) Morphologie fonctionnelle des appendices nutritionnels de Meganyctiphanes norvegica (M. Sars, 1856) et Euphausia krohnii (Brandt, 1851) (Crustacea Euphausiacea). Archs Zool Exp Gen 119:95-106

Baier CT, Purcell JE (1997) Effects of sampling and preservation on apparent feeding by chaetognaths. Mar Ecol Prog Ser 146:37-42

Båmstedt U (1976) Studies on the deep-water pelagic community of Korsfjorden, western Norway. Changes in the size and biochemical composition of Meganyctiphanes norvegica (Euphausiacea) in relation to its life cycle. Sarsia 61:15-30

Banmstedt U (1988) The macrozooplankton community of Kosterfjorden, western Sweden. Abundance, biomass, and preliminary data on the life cycles of dominant species. Sarsia 73:107-124

Barange M, Gibbons MJ, Carola M (1991) Diet and feeding of Euphausia hanseni and Nematoscelis megalops (Euphausiacea) in the northern Benguela current: ecological significance of vertical space partitioning. Mar Ecol Prog Ser $73: 173-181$

Beyer F (1993) Meganyctiphanes norvegica (M. Sars) (Euphausiacea) a voracious predator on Calanus, other copepods, and ctenophores, in Oslofjorden, southern Norway. Sarsia 77:189-206

Dagg MJ, Walser WE (1987) Ingestion, gut passage and egestion by the copepod Neocalanus plumchrus in the laboratory and in the subarctic Pacific Ocean. Limnol Oceanogr $32: 178-188$

Einarsson H (1945) Euphausiacea I. North Atlantic species. Dana Rep 27:1-185

Falk-Peterson S, Gatten RR, Sargent JR, Hopkins CCE (1981) Ecological investigations on the zooplankton community of Balsfjorden, northern Norway: seasonal changes in the lipid class composition of Meganyctiphanes norvegica (M. Sars), Thysanoessa raschii (M. Sars), and $T$ inermis (Krøyer). J Exp Mar Biol Ecol 54:209-224

Fevolden SE (1982) Feeding habits and enzyme polymorphism in Thysanoessa raschii and Meganyctiphanes norvegica (Crustacea; Euphausiacea). Sarsia 67:1-10

Gerritsen J, Strickler JR (1977) Encounter probabilities and community structure in zooplankton: a mathematical model. J Fish Res Bd Can 34:73-82

Gibbons MJ (1993) Vertical migration and feeding of Euphausia lucens at two $72 \mathrm{~h}$ stations in the southern Benguela upwelling region. Mar Biol 116:257-268

Gibbons MJ, Barange M, Pillar SC (1991a) Vertical migration and feeding of Euphausia lucens (Euphausiacea) in the southern Benguela. J Plankton Res 13:473-486

Gibbons MJ, Pillar SC, Stuart V (1991b) Selective carnivory by Euphausia lucens. Cont Shelf Res 11:625-640

Greene CH (1986) Patterns of prey selection: implications of predator foraging tactics. Am Nat 128:824-839

Heyraud M (1979) Food ingestion and digestive transit time in the euphausiid Meganyctiphanes norvegica as a func- tion of the animal size. J Plankton Res 1:301-311

Irigoien X, Castel J, Gasparini S (1996) Gut clearance rate as predictor of food limitation situations. Application to to estuarine copepods: Acartia bifilosa and Eurytemora affinis. Mar Ecol Prog Ser 131:159-163

Karlson K, Båmstedt U (1994) Planktivorous predation on copepods. Evaluation of mandible remains in predator guts as a quantitative estimate of predation. Mar Ecol Prog Ser 108:79-89

Krebs CJ (1972) Ecology. The experimental analysis of distribution and abundance. Harper \& Row, New York

Kulka DW, Corey S, Iles TD (1982) Community structure and biomass of euphausiids in the Bay of Fundy. Can J Fish Aquat Sci 39:326-334

MacDonald R (1927) Food and habits of Meganyctiphanes norvegica. J Mar Biol Assoc UK 14:753-784

Martinussen MB, Båmstedt $U$ (in press) Ecology of gelatinous planktonic predators. Digestion rate in relation to type and amount of prey. J Exp Mar Biol Ecol

Mauchline J (1980) The biology of mysids and euphausiids. Adv Mar Biol 18:1-681

Mauchline J, Fisher LR (1969) The biology of euphausiids. Adv Mar Biol 7:1-454

McClatchie S (1985) Feeding behaviour in Meganyctiphanes norvegica (M. Sars) (Crustacea: Euphausiacea). J Exp Mar Biol Ecol 86:271-284

Murtaugh PA (1984) Variable gut residence time: problems in inferring feeding rate from stomach fullness of a mysid crustacean. Can J Fish Aquat Sci 41:1287-1293

Nederaas K, Smestad OM (1987) Abundance and distribution of postlarvae in the 0-group saithe survey in the North Sea and Northeast Atlantic in 1986 and 1987. Comm Meeting Int Counc Explor Sea 6:31

Nicol S (1984) Cod end feeding by the euphausiid Meganyctiphanes norvegica. Mar Biol 80:29-33

Nicol S (1986) Shape, size and density of daytime surface swarms of the euphausiid Meganyctiphanes norvegica in the Bay of Fundy. J Plankton Res 8:29-39

Ohman MD (1984) Omnivory by Euphausia pacifica: the role of copepod prey. Mar Ecol Prog Ser 19:125-131

Pasternak AF (1994) Gut fluorescence in herbivorous copepods: an attempt to justify the method. Hydrobiologia 292/293:241-248

Peterson W, Painting S, Barlow R (1990) Feeding rates of Calanoides carinatus: a comparison of five methods including evaluation of the gut fluorescence method. Mar Ecol Prog Ser 63:85-92

Price HJ (1989) Swimming behavior of krill in response to algal patches: a mesocosm study. Limnol Oceanogr 34: $649-659$

Price HJ, Boyd KR, Boyd CM (1988) Omnivorous feeding behavior of the Antarctic krill, Euphausia superba. Mar Biol 97:67-77

Rotschild BJ, Osborn TR (1988) Small-scale turbulence and plankton contact rates. J Plankton Res 10:465-474

Sameoto D (1980) Relationships between stomach contents and vertical migration in Meganyctiphanes norvegica, Thysanoessa raschii and $T$. inermis (Crustacea, Euphausiacea). J Plankton Res 2:129-143

Sameoto D, Cochrane N, Herman A (1993) Convergence of acoustic, optical, and net-catch estimates of euphausiid abundance: use of artificial light to reduce net avoidance. Can J Fish Aquat Sci 50:334-346

Sargent J, Falk-Petersen S (1981) Ecological investigation on the zooplankton community of Balsfjorden, northern Norway: lipids and fatty acids of Meganyctiphanes norvegica, Thysanoessa raschii and $T$. inermis during mid- 
winter. Mar Biol 62:131-137

Simmard Y, Lacroix G, Legendre L (1986) Diel vertical migration and nocturnal feeding of a dense coastal krill scattering layer (Thysanoessa raschi and Meganyctiphanes norvegical in stratified surface waters. Mar Biol 91:93-105

Stuart V (1986) Feeding and metabolism of Euphausia lucens (Euphausiacea) in the southern Benguela current. Mar Ecol Prog Ser 30:117-125

Editorial responsibility: Otto Kinne (Editor), Oldendorf/Luhe, Germany
Stuart V, Hugget JA (1992) Prey selection by Euphausia lucens (Hansen) and feeding behaviour in response to a mixed algal and animal diet. J Exp Mar Biol Ecol 164: $117-133$

Stuart V, Pillar SC (1990) Diel grazing patterns of all ontogenetic stages of Euphausia lucens and in situ predation rates on copepods in the southern Benguela upwelling region. Mar Ecol Prog Ser 64:227-241

Submitted: December 17, 1997; Accepted: July 9, 1998

Proofs received from author(s): September 21, 1998 